PNL-7652

UC-350

\title{
Energy-Efficiency Testing Activities of the Mobile Energy Laboratory
}

Semiannual Report:

April 1, 1990, Through September 30, 1990

G. B. Parker

J. W. Currie

March 1991

Prepared for

the U.S. Department of Energy

Federal Energy Management Program

under Contract DE-AC06-76RLO 1830

Pacific Northwest Laboratory

Operated for the U.S. Department of Energy

by Battelle Memorial Institute 


\title{
DISCLAIMER
}

This report was prepared as an account of work sponsored by an agency of the United Stales Government. Neither the United States Government nor any agency thereof, nor Battelle Memorial Institute, nor any of their employees, makes any wartanty, expressed or implied, or assumes any legal liability or responsibility for the accuracy, completeness, or usefulness of any information, apparatus, product, or process disclosed, or represents that its use would not infringe privately owned rights. Reference herein to any specific commercial product, process, or service by trade name, trademark, manufacturer, or otherwise does not necessarily constitute or imply its endorsement, recommendation, or favoring by the United Stales Government or any agency thereof, or Battelle Memorial institute. The views and opinions of authors expressed herein do not necessarily state or refiect those of the United States Government or any agency thereof.

\author{
PACIFIC NORTHWEST LABORATORY \\ operated by \\ BATTELLE MEMORIAL INSTITUTE \\ for the \\ UNITED STATES DEPARTMENT OF ENERGY \\ under Contract DE-ACO6-76RLO 1830
}

Printed in the United States of America

Available to DOE and DOE contractors from the

Office of Scientific and Technical Information, P.O. Box 62, Oak Ridge, TN 37831; prices available from (615) 576-8401. FTS 626-8401.

Available to the public from the National Technical Information Service, U.S. Department of Commerce, 5285 Port Royal Rd., Springfield, VA 22161. 
PNL-7652

UC -350

ENERGY-EFFICIENCY TESTING ACTIVITIES

OF THE MOBILE ENERGY LABORATORY

SEMIANNUAL REPORT:

APRIL 1, 1990, THROUGH SEPTEMBER 30, 1990

G. B. Parker

J. W. Currie

March 1991

Prepared for

the U.S. Department of Energy

Federal Energy Management Program

under Contract DE-AC06-76RLO 1830

Pacific Northwest Laboratory

Richland, Washington 99352 



\section{CONTENTS}

1.0 EXECUTIVE SUMMARY . . . . . . . . . . . . . . . . . . 1

1.1 MANAgEMENT ACTIVITIES . . . . . . . . . . . . . . . . I

1.2 Site testing AND RELATED ACTIVItIES . . . . . . . . . 2

1.3 SIGNIFICANT TEST FINDINGS $\ldots . \ldots$

1.4 EQUIPMENT . . . . . . . . . . . . . . . . . . 5

1.5 DOCUMENTATION AND REPORTING . . . . . . . . . . . . . 5

2.0 PROGRAM DESCRIPTION ....................... . . . . . . . . . .

2.1 SCOPE .......................... . . 7

2.2 ORGANIZATION . . . . . . . . . . . . . . . . . . 7

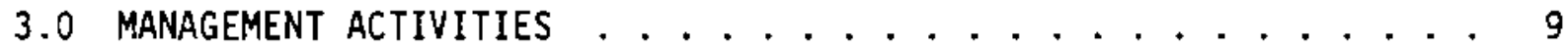

3.1 MEL USE COMMITTEE AND FEMP PROGRAM OVERSIGHT ACTIVITIES . $\quad$.

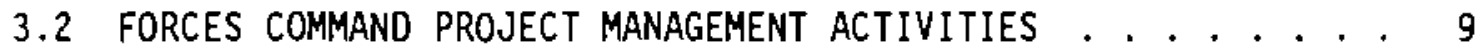

3.3 OTHER DEPARTMENT OF DEFENSE AND FEDERAL AGENCY ACTIVITIES - 10

4.0 TESTING ACTIVITIES AND RESULTS . . . . . . . . . . . . . . . 11

4.1 FORSCOM INSTALLATIONS . . . . . . . . . . . . . 11

4.2 OTHER FEDERAL INSTALLATIONS . . . . . . . . . . 17

5.0 TESTING EQUIPMENT AND MOBILE ENERGY LABORATORIES . . . . . . . . 21

5.1 MOBILE ENERGY LABORATORY VEHICLES . . . . . . . . . . . . . 21

5.2 TESTING EQUIPMENT . . . . . . . . . . . . . . . 21

6.0 REPORTING AND DOCUMENTATION . . . . . . . . . . . . . . . 23

6.1 PRESENTATIONS AND DISPLAYS . . . . . . . . . . . . . . 23

6.2 TEST PROCEDURES . . . . . . . . . . . . . . . . . 23

6.3 INITIAL SITE VISIT REPORTS . . . . . . . . . . . . . 25

6.4 MEL ASSIGNMENT PLANS . . . . . . . . . . . . . . . . 25 
6.5 TEST REPORTS . . . . . . . . . . . . . 25

6.6 OTHER DOCUMENTATION . . . . . . . . . . . . 26

7.0 PlANNED ACTIVITIES . . . . . . . . . . . . . . . 27

7.1 FORSCOM PROJECT ACTIVITIES (PNL) . . . . . . . . 27

7.2 NeESA ACTIVITIES ................... 27

7.3 FEMP, DoD, AND FEDERAL AGENCIES ACTIVITIES . . . . . . . 28

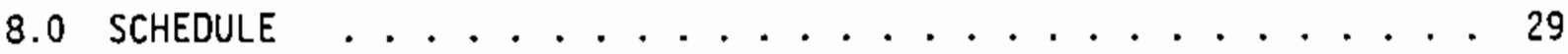

Attachment 1 - Mel uSe committee meeting minutes . . . . . . . . 1.1

ATTACHMENT 2 - PACIFIC NORTHWEST LABORATORY APPRAISAL REPORT FORM - 2.1

ATTACHMENT 3 - STATUS OF FORSCOM MAPS . . . . . . . . . . 3.1

ATTACHMENT 4 - INITIAL SITE VISIT REPORT FORM . . . . . . . . 4.1

ATTACHMENT 5 - MEL WRITEUP FOR SAS CORPS OF ENGINEERS . . . . . 5.1 


\title{
ENERGY-EFFICIENCY TESTING ACTIVITIES \\ OF THE MOBILE ENERGY LABORATORY
}

\author{
SEMIANNUAL REPORT: \\ APRIL 1, 1990, THROUGH SEPTEMBER 30, 1990
}

\begin{abstract}
Sponsor: U.S. Department of Energy Federal Energy Management Program Period: $\quad$ April 1, 1990, through September 30, 1990

Contractor: Pacific Northwest Laboratory, P.0. Box 999, Richland, Washington Contact: Grahan B. Parker (509) 375-3805
\end{abstract}

\subsection{EXECUTIVE SUMMARY}

This report sumnarizes energy-efficiency testing activities applying the Mobile Energy Laboratory (MEL) testing capabilities during the third and fourth quarters of fiscal year (FY) 1990. The MELS, developed by the U.S. Department of Energy (DOE) Federal Energy Management Program (FEMP), are administered by Pacific Northwest Laboratory (PNL) $(\mathrm{a})$ and the Nava] Energy and Environmental Support Activity (NEESA) for energy testing and energy conservation program support functions at federal facilities. The using agencies principally fund MEL applications, while DOE/FEMP funds program administration and capability enhancement activities.

This report fulfills the requirements established in Section 8 of the MEL Use Plan (PNL-6861) for semiannua] reporting on energy-efficiency testing activities using the MEL capabilities. The MEL Use Committee, formally established in 1989, developed the MEL Use Plan and meets semiannualiy to establish priorities for energy-efficient testing applications using the MEL capabilities. The MEL Use Committee is composed of one representative each of the U.S. Department of Energy, U.S. Army, U.S. Air Force, U.S. Navy, and other federal agencies.

\subsection{MANAGEMENT ACTIVITIES}

The MEL Use Committee and MEL applications programs at PNL were brought under the Energy Systems Modernization Office (ESMO) managed by J. W. (Bi11) Currie. This program office is a part of the Infrastructure Modernization (IM) program at PNL. The MEL activities undertaken by PNL for Army Forces Conmand (FORSCOM) are managed for FORSCOM by the Savannah District Corps of Engineers (SAS).

The management of MEL activities at NEESA was transferred from Rick Messock to Jim Heller. Mr. Heller becomes the Navy representative on the MEL Use Committee.

(a) Pacific Northwest Laboratory is operated by Battelle Memorial Institute for the U.S. Department of Energy under Contract DE-AC06-76RLO 1830. 
The semiannual MEL Use Committee meeting was held on March 29 to 30 , 1990, in San Diego, California. The need to revise the MEL Use Plan based on recent PNL experience and the need to add a NEESA operations addendum to the plan were central items of discussion.

Graham Parker and Bill Currie attended the semiannual Forces Command (FORSCOM) Energy Program In-Progress Review Meeting May 15 to 16, I990. Mr. Parker presented material relating to the MEL testing activities at FORSCOM sites, and Bill Currie presented information on utility conservation programs available to FORSCOM installations.

A Pacific Northwest Laboratory Appraisal Report form was developed by PNL and approved by FORSCOM in August 1990. The report will be used to assess the performance of PNL in FORSCOM activities at the sites.

In September 1990, the ESMO recomnended Graham Parker of PNL to replace Richard Mazzucchi as the Executive Secretary of the MEL Use Committee. This was to be confirmed at the MEL Use Committee Meeting in Chicago in October 1990 .

\subsection{SITE TESTING AND RELATED ACTIVITIES}

During the reporting period, initial site visits were conducted by PNL at two FORSCOM sites (Fort Ord and Fort Riley), and eight MEL Assignment Plans (MAPs) were prepared and signed identifying testing to be undertaken at these two sites.

Over 20 tests were conducted at five FORSCOM sites (Forts Carson, Irwin, Stewart, and McPherson, as well as Hunter Army Air Field), one Army Materiel Command (AMC) site (Lake City Army Ammunition Plant), seven U.S. Navy sites (National Naval Medical Center, Naval Air Depot-Pensacola, Public Works Center-San Diego, Marine Corps Base Camp Pendleton, Marine Corps Base Twentynine Palms, Naval Air Station Cecil Field, Naval Hospital-San Diego), one Department of Transportation site (Merchant Marine Academy), one Training and Doctorate Site (Fort Bliss), and three DOE sites (Hanford, Forrestal Building, Fermi National Accelerator Laboratory). At FORSCOM sites alone, over $\$ 2.5$ million of energy savings would be realized if recommendations are implemented based on site testing and analysis.

Significant MEL-related activities at the sites during this reporting period include

- organizing a collaborative effort among FEMP, the Bonneville Power Administration, Tacoma Public Utilities, and Fort Lewis staff to design and implement demand-side (conservation) programs for acquiring electrical energy resources at Fort Lewis - The role of the MEL in the project is to provide baseline data and verification data after implementation of the selected energy conservation projects. 
- evaluating the potential for a shared energy savings (SES) lighting retrofit at the DOE Forrestai Building and Bujlding 200 at Fort McPherson

- undertaking an analysis of the utility rate structure for Fort ord with the goal of the site negotiating a more favorable rate - A savings of \$1 million to \$2 million per year is expected through this rate renegotiation.

- developing and testing new MEL procedures and testing equipment at the Hanford Site - The test procedures for chiller performance were developed and field-tested on two chillers at Hanford. MEL Test Procedure \#11 Chiller Performance Testing was developed from these tests.

- assisting the Merchant Marine Academy to determine if viable SES projects are feasible and to develop energy use baselines for ongoing energy management or contractor payment determinations

- a determination of the site-wide feeder loading for the particle accelerator at Fermi National Accelerator Laboratory for potential load-shedding opportunities

- reviewing the progress of ventilation, steam, and electrical upgrade projects, discussing energy-efficiency testing with the site energy management team, and performing a short-term temperature evaluation study in two of the production bujldings at the Lake City Army Ammunition Plant

- evaluating several U.S. Navy sites for cogeneration opportunities

- testing variable-speed pumps and motors at the Public Works CenterSan Diego to isolate periodic trip-out conditions.

\subsection{SIGNIFICANT TEST FINDINGS}

Significant findings from the testing activity during the reporting period are as follows:

- Approximately $\$ 2700 /$ year is being saved in lighting energy at fort Carson from implementing a lighting conservation program in Building 8030. A potential $\$ 300,000$ year could be saved at the site with a similar conservation program implemented in nonresidential buildings. A final test report was issued this reporting period.

- A fuel savings of about $47,000 \mathrm{MBtu} /$ year (equivalent savings of $\$ 187,000$ ) could be realized with minor modifications to 11 small boilers tested at Fort Carson. This could be accomplished with adjustments in the fuel-air mixtures and installation of combustion air pre-heaters. A final test report was issued this reporting period. 
- The relatively new commissary at fort Lewis used electrical power at the rate of $390 \mathrm{kWh} /$ day, which corresponds to an energy use intensity of $49 \mathrm{kWh} / \mathrm{ft}^{2}-\mathrm{yr}$. The energy consumption was significantly less (and therefore not excessive) compared to other similar-type buildings in the region. A final test report was issued this reporting period.

- Electrical usage data continued to be collected at fort Irwin in two office buildings and at the central substation. Initial data from the two office buildings indicate that the heat pumps in the buildings many times operate unnecessarily in heating and cooling mode simuitaneousiy. In addition, the combined units for the buildings appear to be oversized. Final test reports for these two tests will be issued the first quarter of FY9l.

- Chiller testing at Hunter Army Air Field was conducted in September 1990. Three central chiller plants were tested, one each in Buildings 1323, 1243, and 1450. In general, none of the chillers tested was operating at anywhere near optimum efficiency due to inattention paid to operations and maintenance of the units. A final test report will be issued the second quarter of FY9l.

$\therefore$ Data collected on Building 200 at Fort HCPherson during the summer show a peak demand in excess of $2700 \mathrm{kH}$, a significant peak for a building of that size. Data collection will continue through the second quarter of FY9l to capture heating season data. Analys is and reporting are expected to be completed in the third quarter of Fy91.

- Boiler combustion/delivery efficiency data were collected on two central boilers at Fort McPherson until April 1990 when the boilers were unexpectedly shut down due to a leak and general failure of boiler tubes. A draft test report was issued during the reporting period.

- Electrical end-use metering was conducted in the DOE Forrestal Building. The information will be used to improve energy management at the building and to assist in the evaluation and potential implementation of an SES retrofit of the lighting systems. The data reveal that the largest electrical uses in the building are lighting $(32.7 \%)$, receptacles $(11.3 \%)$, and computers $(9.5 \%)$. A solicitation for an SES lighting project will be issued the first quarter of FY91.

- Data are being collected at the National Naval Medical Center to determine the electric load profiles of the largest buildings at the site, to assess SES opportunities. Preliminary analyses revealed that a significant fraction of electrical consumption occurs during nonworking periods. The data also provided useful energy consumption baselines for individual buildings. 
- The central steam plant at the Marine Corps Base Twentynine Palms

was tested by NEESA to determine the cause of vibration in the

primary loop header and inadequate building heating in the

distribution system. Pressures, temperatures, and flows were

measured to isolate the primary cause of the poor system

performance. Recommendations were made for replacing system

components and changing operating practices at the plant.

\subsection{EQUIPMENT}

During the reporting period, the Air Force MEL was moved from Fort Carson to PNL, and the equipment on the bus was inventoried, calibrated, and repaired.

Several new pieces of equipment were either ordered or acquired during the reporting period; they will enhance site testing, data acquisition, and analyses activities. The equipment, valued in excess of $\$ 90,000$, was purchased with FEMP equipment funds, MEL equipment replacement (use rate) funds, and internal PNL funding for enhancement of the PNL metering and testing laboratory, as well as acquired as transferred or excess equipment at no cost to the project.

An excess portable computer was acquired and modified for data collection at remote sites where no phone lines are available. PNL has also purchased and tested a portable phone and modem for use at remote sites where no phone line is available but where cellular service is.

PNL developed a Serial Port Acquisition and Reduction (SPARe) software and an interface that will allow direct (remote) recording from a Dranetz 808 analyzer (a) through a phone 1 ine and modem. This technology was also adapted for use with the Engineering Measurements Company (EMCO) $4200^{(b)}$ flow meters for chiller water flow measurements. In addition, a less expensive type of valve assembly was designed and assembled for use with EMCO flow meters in chiller testing applications.

\subsection{DOCUMENTATION AND REPORTING}

Four test reports were completed, reviewed, and submitted to the site this reporting period. These were

- Test Report CARSON-001-90/07/03 Building 8030 Lighting and End-Use Metering

- Test Report CARSON-002-90/06/18 Combustion Efficiency/Waste 0i1 Burn

\footnotetext{
(a) Dranetz Technologies, Inc., Edison, New Jersey.

(b) Engineering Measurements Company, Longmont, Colorado.
} 
- Test Report IRWIN-003-90/08/01 Measured Lighting Levels in Four office Buildings

- Test Report FTSAMH-001-90/02/12 Air Conditioner Controller Evaluation. were

Three test reports were drafted and submitted to SAS for review. These

- Test Report LEWIS-005-90/07/27 Commissary Electric Profile

- Test Report FTMAC-001-90/07/26 Boiler Combustion/Delivery Efficiency

- Test Report FTMAC-003-90/08/22 Combustion Efficiency of 10 Small Boilers.

In addition, the following significant documents and reports were prepared during the reporting period:

- MEL Test Procedure \#1 Electrical End-Use Metering and the MEL Application Plan Development Guide were submitted to the American Society for Testing and Materials (ASTM) Standards Committee for balloting and comment.

- Six MEL test procedures were drafted. Five of these have undergone Corps of Engineers review, and one is currently in the review process. Ten additional test procedures are in various stages of development.

- Two Initial Site Visit reports were prepared for two FORSCOM sites, leading to the development and signing of eight MAPs. 


\subsection{PROGRAM DESCRIPTION}

The U.S. Department of Energy (DOE) Federal Energy Management Program (FEMP) provides leadership and assistance to federal agencies on energy management issues. Because much of the federal infrastructure is old and was built when energy was of relatively low value and cost, it now presents tremendous challenges and opportunities for energy-efficiency improvement. FEMP has developed this unique program of technical support and guidance to assist federal agencies in identifying and implementing cost-effective energysaving projects.

\subsection{SCOPE}

Mobile Energy Laboratories (MELs) are equipped by FEMP for the on-site evaluation of energy use efficiency. Energy use metering and analys is equipment is provided to test the efficiency of energy conversion and distribution systems, as well as the various end-use applications. Specific test procedures are being developed for common investigations. Trained engineers and specialists conduct tests with the assistance of host facility staff and contractors.

Reports are produced to describe the testing, test results, and suggested courses of action. These reports can be used to justify changes in operating procedures, maintenance efforts, system designs, or energy-using equipment. The MEL capabilities are also instrumental in the development of integrated resource plans for federal facilities and can be used to assess the results of energy conservation and load management projects.

\subsection{ORGANIZATION}

Four MELs have been configured for use on federal facilities. Although the MELs are the property of DOE, a MEL is assigned to each of the following federal agencies: 1) Department of the Army, 2) Department of the Navy, 3) Department of the Air Force, and 4) the U.S. Department of Energy. The $M E L$ Use Plan (PNL-686I) recognizes the need for, and advantages of, centralized administration, test procedure development, and operator training. The DOE assigns new equipment and upgrades existing equipment as new capabilities are deveioped. The equipment, engineers, and specialists are made avaitable to federal agencies and installations who provide funding for the direct costs associated with MEL applications.

Pacific Northwest Laboratory (PNL) is responsible for MEL maintenance, equipment calibration, test procedure development, testing, and overall management and reporting requirements for applying three of the MELs (Army, Air Force, and DOE). The Naval Energy and Environmental Support Activity (NEESA) is responsible for these activities involving Navy MEL applications. Both PNL and NEESA work with the MEL Use Committee to coordinate assignments of MELs with federal agencies. 



\subsection{MANAGEMENT ACTIVITIES}

In 1988, DOE assigned PNL the responsibility for MEL administration and management to better coordinate and enhance MEL applications. Four MELs were originally configured in 1985 by NEESA for DOE and delivered to the agencies identified in Section 2 for application. Three of the MELs are now managed by PNL for use by any federal agency, with NEESA managing the fourth MEL for Navy activities.

\section{I MEL USE COMMITTEE AND FEMP PROGRAM OVERSIGHT ACTIVITIES}

The MEL Use Committee and MEL applications programs at PNL were brought under the Energy Systems Modernization Office (ESMO) managed by J. W. (Bii1) Currie (509) 375-3969. This program office is a part of the Infrastructure Modernization (IM) office at PNL. Mr. Currie is responsible for MEL and MELrelated program oversight and program development activities at PNL. In September 1990, the ESMO appointed Graham Parker of PNL to replace Richard Mazzucchi as the Executive Secretary of the MEL Use Committee. Mr. Mazzucchi had served as the Executive Secretary since the committee's inception in 1988.

The semiannual MEL Use Committee meeting was held March 29 through 30 , 1990, in San Diego, California. The minutes of the meeting are given in Attachment 1. The need to revise the MEL Use Plan based on recent PNL experience and the need to add a NEESA operations addendum to the plan were discussed. The committee agreed to act upon proposed revisions at the next committee meeting. Other significant activities at the meeting included reaching a decision regarding allocation of new FEMP equipment funds between PNL and NEESA, an agreement by FEMP to determine its policy toward MEL applications at non-federal agencies (such as the Urban Mass Transit Authority), and a commitment to continue to assess the U.S. Air Force (USAF) interest in promoting/leading MEL applications at selected USAF Logistics Command centers.

With support from K. Dean Devine at FEMP, a MEL was displayed at the DOE Forrestal Building during National Energy Awareness Week in October 1990 and at the PNL open house in Richland in May 1990. A poster was prepared by ESMO to provide an overview of the MEL and offer an invitation to come onboard and see the metering equipment.

\subsection{FORCES COMMAND PROJECT MANAGEMENT ACTIVITIES}

The Army Forces Command (FORSCOM) MEL activities are funded by Jim Vasiloff at FORSCOM and managed by Graham Parker at PNL (509) 375-3805. The day-to-day technical management and review activities of the FORSCOM project are managed for Mr. Vasiloff by the Savannah District Corps of Engineers (SAS).

Graham Parker and Bill Currie attended the semiannual FORSCOM Energy Program In-Progress Review Meeting May 15 to 16, 1990. Mr. Parker presented material relating to the MEL testing activities, and Mr. Currie presented information on utility conservation programs available to FORSCOM 
installations. The potential for large utility-sponsored energy-efficiency programs at Fort Lewis was specifically discussed.

The PNL FORSCOM/MEL management team and Bill Currie met with Jim Vasiloff at PNL on August 27, 1990, to discuss the current status of the project.

Discussions centered around recent testing results, schedule of activities in Fiscal Year (FY) 1991 and beyond, and anticipated funding to support those activities.

Graham Parker prepared a statement of work (SOW) for new FORSCOM funding expected in FY90 and FY91. As part of the SOW, several options were developed to allocate the funding. A key feature to the future work is transferring the routine testing technology to qualified subcontractors.

As a related activity to the SOW preparation, the PNL Project Management $P$ lan for MEL activities was revised and signed, reflecting how PNL will manage the changing current and future MEL activities for FORSCOM.

A Pacific Northwest Laboratory Appraisal Report form was developed by PNL and approved by FORSCOM for assessing the performance of PNL in FORSCOM activities at the sites (see Attachment 2). These forms are to be mailed by PNL to the sites in November and December 1990 and returned to Jim Vasiloff for review.

\subsection{OTHER DEPARTMENT OF DEFENSE AND FEDERAL AGENCY ACTIVITIES}

These activities at PNL are managed by Bill Currie and partially supported by K. Dean Devine of FEMP.

Rich Mazzucchi attended the technical sessions of the 70th Annual Meeting of the Society of American Military Engineers (SAME) in Dayton, Ohio, on May 10, 1990. He met with Gary DeVeny of the Air Force Logistics Command WrightPatterson Air Force Base to discuss MEL operations and activities and to collect information on the SAME organization. No commitments were made concerning Logistics Command or Air Force participation in MEL applications.

Bill Currie presented material on utility demand-side management offerings to Department of Defense (DoD) sites at the April 1990 meeting of the U.S. Army Corps of Engineers Nationa] Energy Team (CENET). 


\subsection{TESTING ACTIVITIES AND RESULTS}

\subsection{FORSCOM INSTALLATIONS}

The current status of Mel Assignment Plan (MAP) testing activities at FORSCOM sites is given in Attachment 3, STATUS OF FORSCOH MAPS. An estimated total savings of approximately $\$ 2.5 \mathrm{million} /$ year would be realized at FORSCOM sites if recommendations based on testing and other activities undertaken during this reporting period are implemented.

\subsubsection{Fort Carson}

An initial site visit was conducted at Fort Carson in January 1989. Testing activities were initiated in January 1989 and are continuing. The point of contact at Fort Carson is Steve Snyder (719) 579-3678.

\subsubsection{Testing and Reporting Activities}

Testing for MAP CARSON-001 was completed, and Test Report CARSON-00190/05/31 Building 8030 Lighting and End-Use Hetering was reviewed by SAS and transmitted to the site in June 1990. Test Report CARSON-002-90/06/18 Combustion Efficiency/Naste Oil Burn was also completed and reviewed by SAS before it was transmitted to the site in July 1990.

The final analysis in CARSON-001-90/05/31 indicated that $\$ 2700 /$ year is being saved in lighting energy from implementing the Tighting conservation program in Building 8030 . Further, a potential $\$ 300,000 /$ year could be saved at the site with a similar conservation program implemented in nonresidential buildings.

The anatysis in CARSON-002-90/06/18 showed that a fuel savings of about $47,000 \mathrm{MBtu} /$ year (equivalent savings of $\$ 187,000$ ) could be realized with minor modifications to the 11 boilers tested. This could be accomplished with adjustments in the fuel-air mixtures and installation of combustion air preheaters. The burning of waste $0 i 1$ in the boilers, whose primary function is to provide process heat, space heat, or domestic hot water, should be discontinued due to loss of efficiency with soot accumulation on the boiler tubes.

PNL visited the site in July to remove some test equipment, return the bus (Air Force MEL) to PNL, and correct a metering equipment installation error at Building 8000 (CARSON-003). Data collection was required through September 1990 for CARSON-003 after the error was corrected, in order to collect sufficient data for final analysis and reporting.

\subsubsection{Other Activities}

Steve Snyder requested FORSCOM support using PNL expertise to assist the site in the development and installation of a site-wide automated meter reporting and control system. Mr. Snyder indicated that the site may be 
willing to co-fund such a project. A site visit was scheduled by PNL in late October 1990 to discuss the potential project with Mr. Snyder.

\subsubsection{Fort Lewis}

An initial site visit was conducted in May 1989, and testing was initiated in September 1989. Nine MAPs were prepared: six were approved, and three tests have been completed. The point of contact for MEL testing activities at Fort Lewis is Jim Thayer (206) 967-5237.

\subsubsection{Testing and Reporting Activities}

Test Report LEWIS-005/90/07/27 Comissary Electric Profile was drafted and sent to SAS for review in August 1990. The test resuits indicated that the relatively new commissary at the site used electrical power at the rate of $390 \mathrm{kWh} /$ day, which corresponds to an energy use intensity of $49 \mathrm{kgh} / \mathrm{ft}^{2}-\mathrm{yr}$. The energy consumption in this structure was significantiy less and therefore not considered excessive compared to other similar-type buildings in the region being metered by PNL.

The data analysis for test report for LEWIS-002 (substation monitoring) was nearly completed during the reporting period. The draft report was expected to be sent to SAS for review in october 1990 .

\subsubsection{Other Activities}

Significant activity at the site during the reporting period involved the process of securing support from FEMP, Tacoma Public Utilities (the servicing utility), the Bonneville Power Administration (the federal power marketer who provides the electrical power to the utility), and Fort Lewis staff in a collaborative effort to design and implement demand-side (conservation) programs to acquire power (load) resources from the site. The utility is motivated to acquire cost-effective resources from the site to meet anticipated load growth. The goal is to acquire large projects at the site that do not require military construction funds and that minimize procurement. Initialiy, as much as $\$ 12$ million to $\$ 15$ million may be available from the utility for projects at the site.

The Fort Lewis staff identified 11 project areas for which energy, cost, and simple payback information were developed for possible candidates as resource acquisition for the utility. PNL's role is working with Bonneville and the utility to establish the financing mechanisms for implementing the energy conservation projects while at the same time developing the energy conservation supply curves for the various energy use sectors at the site. The initial focus is on electricity savings to support the development of one or more proposals that the utility may offer Bonneville. A target date of January 1991 has been established for drafting the proposed projects and requesting funding to begin the projects in the spring of 1991.

The role of the MEL in the project is to provide baseline data and verification data after implementation of the seiected energy conservation 
projects. The point of contact for these activities at the site is Newel] Flood (206) 967-5237.

\subsubsection{Fort Irwin}

An initial site visit was conducted at Fort Irwin in September 1989, and three MAPs were developed and signed. Testing activities were initiated in December 1989 and are schedule to be completed during the first quarter of FY9l. The point of contact at the site is Linda Osborne (619) 368-4347.

\subsubsection{Testing and Reporting Activities}

Data continued to be collected for IRWIN-002 (office building metering) and IRWIN-003 (substation metering) through the sumer peaking months, ending in October 1990. Data analysis was started for these two tests in September 1990. A significant amount of spring and early summer data for IRWIN-003 were lost because a lightening strike burned the data logger phone line and circuitry. The logger and telephone line serving the logger were replaced in June 1990.

Initial data from IRWIN-003 indicate that the heat pumps in the buildings operate unnecessarily many times in heating and cooling mode simultaneousiy. In addition, the combined units for a building module appear to be oversized. Final data analysis and reporting will be undertaken in the second quarter of FY91.

Comments were received from the Fort Irwin staff on Test Report IRWIN003-90/02/09 Measured Lighting Levels in Four Office Buildings. PNL responded to each comment and revised the report in July 1990. The report was sent to SAS for transmittal to the site. The testing indicated that significant modifications to the lighting fixtures and design in the old and new modular office buildings can result in significant energy savings with a short payback. Annual savings of over $\$ 200,000$ can be readily achieved by delamping and fixture upgrading involving all modular office buildings at the site plus design changes in all new office buildings at the site.

\subsubsection{Other Activities}

The site is being considered by PNL and FEMP as a candidate site to test and evaluate simple cost-effective technologies for reducing energy that have not yet penetrated the private sector. One technology being considered is that of metal-fabrjc "new generation" sunscreens for window exterjors of sma]l buildings. Should a decision to initiate this activity be made, testing would not begin until the second quarter of FY9l.

The site is also being considered by PNL, FEMP, and FORSCOM as a candidate for the same type of resource acquisition and conservation program evaluation that is being implemented at Fort Lewis. Review of the servicing utility programs offered to the site has indicated that a considerable number of utility demand-side offerings are available to the site. Examination of 
the data from the substation metering indicates that there is tremendous potential for demand savings.

\subsubsection{Fort Sam Houston}

An initial site visit was conducted at Fort Sam Houston in August 1989. Three MAPs were prepared and signed. Testing was initiated in August 1989 and scheduled again for the first quarter of Fygl. The point of contact at the site is Kaya Cibildak (512) 221-0105.

\subsubsection{Testing and Reporting Activities}

Preparations for chiller testing (FTSAMH-002) were made during a site visit in August 1990. The PNL engineer identified locations for flow meter tap locations and electrical metering points, and documented chiller parameters that affect the testing configuration and analyses. Six chillers were selected for testing, and flow meter locations were tagged for valve installation by the site personnel. In addition, current transformers (CTs) were installed in the control cabinets for measuring power consumption.

\subsubsection{Fort Stewart/Hunter Army Air Field (AAF)}

An initial site visit was conducted at Fort Stewart and Hunter Army Air Field (AAF) in October 1989. Two MAPs each were prepared and approved for Fort Stewart and Hunter AAF in January 1990. Testing was initiated in February 1990 and continues at both sites. The site contact at Hunter AAF is Jerry Bridgers (912) 352-5427. The site contact at Fort Stewart is Randy Jones (912) $767-4798$.

\subsubsection{Testing and Reporting Activities}

Data continued to be collected remotely from Fort Stewart on the substation (STWRT-001-Rl) and the main power plant (STWRT-002-Rl) since beginning the tests in February 1990. Since June 1990, data are being collected remotely on the substation at Hunter AAF (HUNTR-001) using a specially-configured portable computer left at the site. Site personnel periodically extract the data from the portable computer and ship the data diskettes to PNL for archiving and analysis.

Chiller testing (HUNTR-002) was conducted in September 1990. Three central chiller plants were tested, one each in Buildings 1323,1243 , and 1450. In general, none of the chillers tested was operating at anywhere near optimum efficiency. The refrigerant in the Building 1323 chitler was so low that testing could not be initiated until it was charged, and the bearing noise during or just prior to unloading was also distressing for this 5-yearold chilier. The controls for the chilier in Building 1243 were significantly out of adjustment. In addition, the chilled water and condenser water pumps in Building 1450 were operating for an unnecessary number of hours during the day. All of these findings were pointed out to the site operations and maintenance staff. Data analysis and reporting will be completed during the second quarter of FY91. 
During this site visit, the equipment was inspected for the three ongoing test at the sites. The equipment for STWRT-001-Rl was removed because sufficient data were taken during the summer peak period. However, an installation error was discovered for HUNTR-001, and the error was corrected.

Because of this error, and because insufficient data were captured during the summer months due to the malfunctioning on-site computer used for data collection, the equipment will remain at the site through the summer of 1991 . It was also decided to leave the equipment for STWRT-002-RI and continue to collect data until the second quarter of FY91, to capture winter heating season data.

\subsubsection{Fort McPherson}

An initial site visit was conducted at Fort McPherson in November 1989. Three MAPs were prepared and signed in December 1989. Testing activities were initiated in January 1990 and continue through the second quarter of FY91. The site contact is Deborah Rowell (912) 752-2071.

\subsubsection{Testing and Reporting Activities}

The data for FTMAC-002 (Building 200 Electric Profile) collected during the second quarter of FY90 were examined. It was apparent that the data collection device failed during the test period. The data are collected with a Dranetz 808 analyzer (a) and recorded on a Techtran 990 recorder $(b)$. The data recorder was replaced in August 1990, and data continued to be successfully collected by site personnel and mailed to PNL. Sumner demand data show a peak demand in excess of $2700 \mathrm{~kW}$, a significant peak for a building of that size. Data collection will continue through the second quarter of FY9l to capture heating season data. Analysis and reporting are expected to be completed in the third quarter of FY9l.

Data continued to be collected for FTMAC-001 (boiler combustion/delivery efficiency) until near the end of April 1990 when the boilers were unexpectedly shut down due to a leak and general failure of boiler tubes. A decision was made to replace the two boilers, and PNL provided data in May 1990 to the Directorate of Engineering and Housing (DEH) to support a design analysis of new boilers.

Drafts of test reports FTMAC-001-90/07/26 Boiler Combustion/Delivery Efficiency and FTMAC-003-90/08/22 Combustion Efficiency of 10 Small Boilers were sent to SAS for review. Comments on the reports were received in September 1990 and are being revised by PNL for resubmission to SAS in the first quarter of FYgl.

\footnotetext{
(a) Dranetz Technologies, Inc., Edison, New Jersey.

(b) Techtran, Inc., Rochester, New York.
} 


\subsubsection{Other Activities}

A survey and characterization was conducted by PNL in Building 200 at the site to assess the feasibility of shared energy savings (SES) opportunities. This work, supported by FEMP, was conducted in August 1990. The study concluded that there was perhaps an opportunity for proceeding with solicitation for an SES lighting and controls project. The report is currently being reviewed by FEMP and FORSCON to determine follow-on activities to be implemented early in Fy91.

\subsubsection{Fort Gillem}

An initial site visit was conducted at Fort Gillem in November 1989. Two MAPs were prepared and signed in December 1989. Testing activities were initiated in January 1990. The site contact is Deborah Rowel1 (912) 752 2071 .

\subsubsection{Testing and Reporting Activities}

No activities were undertaken at Fort Gillem during the reporting period. Testing for the two MAPs wiTl be initiated during the second quarter of Fy9l.

\subsubsection{Fort ord}

An initial site visit was conducted at Fort Ord in April 1990. Five MAPs were prepared and signed in August 1990. No testing activities have been undertaken at the site. The site contact is Rene de la Fuente (408) 2422052.

\subsubsection{Testing and Reporting Activities}

The site visit was documented in Report No. FTORD-SVI-90/04/17 Initial Site Visit Report for Fort Ord identifying six possible tests at the site. After review and consultation with SAS, five MAPs were ultimately prepared by PNL for signatures. The MAPs were signed too late in the reporting period to begin testing for those tests that must be conducted during the summer season (FTORD-001, FTORD-002, and FTORD-003). These tests were therefore delayed until the third quarter of FY91. Hinter testing involving FTORD-004 and FTORD-005 is scheduled for the first quarter of FY9I.

\subsubsection{Other Activities}

At the request of $\mathrm{Mr}$. de la Fuente through FORSCON, PNL has undertaken an analysis of the utility rate structure with the goal of the site negotiating a more favorable rate. Information has been collected on electricity and gas usage on a monthly load and usage basis by utility account number, by rate schedule, and by customer class. The host utility (Pacific Gas \& Electric [PG\&E]) agreed to provide time series fuel usage data to support the load analysis. Other data examined include PG\&E gas and electric tariff schedules, contract folders for development over time in the major utility accounts, inventory and self-generation capabilities at the site, electric and gas 
distribution studies for the site, and the site's monthly Defense Energy information Survey report. It is estimated that the site will be able to save up to $\$ 2$ million/year in utility costs through this analysis and rate renegotiation. The procedure used in this analysis will be applicable to other FORSCOM sites.

\subsubsection{Fort Riley}

An initial site visit was conducted at Fort Riley in July 1990 . Three MAPs were prepared and signed by the site DEH in August 1990. FORSCOM was expected to approve the MAPs in October 1990 pending FY91 funding. The site contact is Steve Pientka (913) 239-2371.

\subsubsection{Testing and Reporting Activities}

The initial site visit was documented in Report No. FTRILEY-SV1-90/07/24 Initial Site Visit For Fort Riley jdentifying three tests. The report was reviewed by SAS, and three MAPs were prepared by PNL and sent to the site for signature. Testing is scheduled to begin during the second quarter of FY9l depending upon the FY91 funding allocation from FORSCOM.

\subsection{OTHER FEDERAL INSTALLATIONS}

MEL testing and testing-related activities were undertaken at several Department of Energy and other Department of Defense installations during the reporting period. The results of this activity are summarized in the following paragraphs.

\subsection{DOE Hanford Site/Hanford Energy Conservation Project}

The major goal of the Hanford Energy Conservation Project (HECP) is to increase energy efficiency, cost-effectively, at the Hanford Site through the cooperative efforts of all site contractors and between site research and development and operations and constructions personnel. This is done through the identification of potential energy conservation opportunities, integration of research and development into projects, and information exchange.

The Hanford Site has been used as a testbed for developing MEL procedures and testing equipment. Although not directly funded by $\mathrm{HECP}$, some of the MEL procedures have been developed as part of HECP projects. In addition, PNL staff assigned to the MEL project have also been the primary technical staff involved in the HECP.

During the reporting period, the chiller performance testing techniques were developed and field-tested on two chillers at Hanford with some support from HECP. MEL Test Procedure \#11 Chiller Performance Testing was subsequently developed from these tests. In addition, PNL provided assistance to Hestinghouse Hanford Company in a steam distribution system leak test. A simple test procedure was being developed, and the application of the procedure and results will be integrated into the continued development of MEL Test Procedure \#6 Stean Distribution System Evaluation. 


\subsubsection{DOE Forrestal Building}

Electrical end-use metering was conducted in May 1990 using two MEL portable data loggers. The information witl be used to improve energy management practices at the building and assist in the evaluation and potential implementation of an SES retrofit of the lighting systems. Hourly load profiles for -50 electrical panels were collected, as were two time measurements of -137 panels to determine occupied and nonoccupied lighting loads. The data were analyzed to produce load profiles for lighting and whole-building electrical use data during working and nonworking time periods. In addition, schedules for plug loads and motor control centers were developed and documented.

The data revealed that the largest electrical uses in the building are lighting (32.7\%), receptacles (11.3\%), and computers $(9.5 \%)$. The SES solicitation was expected to be developed during the first quarter of FY91. The testing procedures developed in this activity will be documented and applied to other SES evaluations for FEMP.

\subsubsection{National Naval Medical Center (NNMC)}

Data are being collected by the NNMC staff using Dranetz 808 analyzers to determine the electric load profiles of the largest buildings at the site. Data diskettes have been received and are being analyzed to indicate candidate buildings for energy conservation programs, including SES opportunities.

Preliminary analyses revealed that a significant fraction of electrical consumption occurs during nonworking periods. The data also provided useful energy consumption baselines for individual buildings. PNL returned to the site in September 1990 to conduct connected load surveys of the major buildings and identity flow metering points for possible steam and chilled water delivery efficiency tests at the central plant.

\subsubsection{Merchant Marine Academy (MMA)}

PNL is assisting the MMA to determine if viable SES projects are feasible and to develop energy use baselines for ongoing energy management or contractor payment determinations. As part of this project, boiler efficiency measurements were taken in May 1990. However, the boiler loads were insufficient for a conclusive flue gas analysis. The boiler log data were encoded into a spreadsheet for analysis, and the electrical services to the largest buildings were surveyed in preparation for metering. The boiler tests will be conducted again in the winter of FY9l in conjunction with a steam meter calibration.

\subsubsection{Fermi National Accelerator Laboratory (FERMILAB)}

Testing at FERMILAB is conducted by site personnel using MEL equipment. Monitoring was conducted to determine the site-wide feeder loading for the particle accelerator. Metering was conducted using Dranetz 808 analyzers and has identified the maximum demand for each feeder as well as the power factor. 
Potential load-shedding projects will be evaluated prior to operating the accelerator again during the second quarter of FY9l. This testing activity was directed by Bill Riches of FERMILAB (708) 840-3779.

\subsubsection{Lake City Army Ammunition Plant (AAP)}

The Army Materiel Comnand (AMC) Lake City AAP is scheduled to undergo a significant modernization program including rebuilding the electrical distribution system, retrofitting and upgrading production facilities buildings, and refurbishing the central steam distribution system. As part of the design of these projects, baseline information is required, as is information for assessing opportunities for energy-efficiency improvements. PNL has provided technical assistance to the site in evaluating these projects and assessing energy-efficiency opportunities.

A visit to the site was conducted in August 1990 to review the progress of the upgrade projects, discuss energy-efficiency testing with the site energy management team, and perform a short-term temperature evaluation study in two of the production buildings. Based on this visit, PNL prepared a statement of work to perform energy-efficiency testing and continue providing the site technical assistance. It is expected that the work will be funded in the second quarter of FY91. The results of the temperature study were expected to be available in late October.

\subsubsection{Naval Energy and Environmental Services Activity (NEESA) Testing}

MEL activities undertaken by NEESA are directed by Jim Hel]er (805) 9823534. Selected NEESA testing activities during the reporting period are summarized as follows:

- NEESA is working with the Naval Air Depot (NADEP) Pensacola, Florida, to install remote meters in each of the site facilities. Stean meters were purchased, and installation is planned for the first quarter of FY9l.

- Testing was conducted on several variable speed pumps at the Public Works Center (PWC)-San Diego to determine why the pumping station was periodically tripping out. The testing isolated the problem, and the station has operated successfully at steady pressure without trip-out.

- Several sites were evaluated for potential cogeneration opportunities including Marine Corps Base (MCB) Camp Pendleton, Naval Air Station (NAS) Cecil Field, and Naval Hospital-San Diego.

- Remote electrical power metering was implemented at Fort Bliss for evaluating potential SES projects.

- The central steam plant at the MCB Twentynine Paims, California, was tested to determine the cause of vibration in the primary loop header and inadequate building heating in the distribution system. 
Pressures, temperatures and flows were measured to isolate the primary cause for the poor system performance. Recommendations were made for replacing system components and changing operating practices at the plant. 


\subsection{TESTING EQUIPMENT AND MOBILE ENERGY LABORATORIES}

For the testing performed by PNL this reporting period, all test equipment was transported in packing boxes via air cargo to the sites. This has been demonstrated to be the most cost-effective means of transporting equipment. The staging and packing of the equipment is done in the PNL metering and testing laboratory that was established during the first quarter of FY90.

\subsection{MOBILE ENERGY LABORATORY VEHICLES}

The Air Force MEL was moved from Fort Carson, Colorado, to PNL in July 1990. The equipment on the bus was inventoried, calibrated, and repaired as necessary. Prior to the move, the rear window seal was replaced. No significant mechanical problems were encountered during transport. The Air Force MEL joins the Army MEL currently based in Richland. The DOE MEL remained at the National Naval Medical Center during this reporting period, but is scheduled to be moved to the Merchant Marine Academy for testing during the first quarter of FYgl.

\subsection{TESTING EQUIPMENT}

Several new pieces of equipment were either ordered or acquired during the reporting period. This equipment will enhance site testing, data acquisition, and analysis activities. The equipment, valued in excess of $\$ 90,000$, was either purchased with FEMP equipment funds, MEL equipment replacement (use rate) funds, or internal PNL funding for enhancement of the PNL metering and testing laboratory, or acquired as transferred or excess equipment at no cost to the project. This equipment includes

- four Synergistics C180 data loggers(a)

- a high-powered data collection and analysis computer

- four portable field computers

- two portable printers

- portable radio frequency license

- power analyzer (rented)

- EMCO FP-I00 flow computer (b) , four extractors, six turbines

- two desktop laser printers for data graphics

- cellular phone and modem

- Transmation (c) pressure calibration system

- ultrasonic thickness gauge

- combustion analyzer

- thermostatic calibration bath

- current probe

(a) Synergistics Control Systems, Inc., New Orleans, Louisiana.

(b) Engineering Measurements Company, Longmont, Colorado.

(c) Transmation Inc., Rochester, New York. 
- phase sequencer and motor rotation indicator

- halogen leak detector

- portable manometer and thermometer

- label printer

- miscellaneous software for upgrading portable field computers.

PNL has undertaken significant test equipment development as well as purchased new test equipment during this reporting period. An excess portable computer was acquired and modified for data collection at remote sites where no phone lines are available. The computer has initially been deployed in the Fort Stewart substation metering activity, and site personnel periodicaliy collect the data on diskettes and majl them to PNL. PNL has also purchased and tested a cellular phone and modem for use at remote sites where no phone line is available. This is the best alternative to the site personne? collecting data on diskettes from a computer, so long as the site is within a cellular phone service area.

There have been repeated faiTures in the field with the drive mechanism of Techtran 990 data recorders used primarily with Dranetz 808 analyzers. PNL therefore developed a Serial Port Acquisition and Reduction (SPARe) software and an interface that will allow direct (remote) recording from a Dranetz in the field through a phone line and modem. This technology was also adapted for use with the EMCO 4200 flow meters for chiller water flow measurements.

Six EMCO flow meters at Hanford were used in a demonstration of SPARe in August. The on-line data reduction of SPARe was successful and proved to be an absolute requirement to reduce data collection from 2.5 megabytes/day to 35 kilobytes/day for this test.

An alternative type of valve assembly was designed and assembled for use with EMCO flow meters in chiller testing applications. Chiller testing does not require the high-pressure/temperature types of assemblies required for steam flow testing. The cost for the new type of assembly is approximately $\$ 200$ less than that of the equivalent assembly used for steam testing. 


\subsection{REPORTING AND DOCUMENTATION}

\subsection{PRESENTATIONS AND DISPLAYS}

The Army MEL and equipment were displayed at a PNL open house in May. The following MEL-related presentations were made by PNL staff during this reporting period:

- "Energy Efficiency Testing Activities Using the Mobile Energy Laboratory." Presented at the Semiannual FORSCOM Energy Program InProgress Review Meeting May 15-16, 1990, Savannah, Georgia.

- "Utility Conservation Programs Available to FORSCOM Installations." Presented at the Semiannual FORSCOM Energy Program In-Progress Review Meeting May 15-16, 1990, Savannah, Georgia.

- "Utility Conservation Programs Available to Army Installations." Presented at the Spring 1990 Meeting of the U.S. Army Corps of Engineers National Energy Team, Aprit 17-19, 1990, Monterey, California.

- "Review of FEMP-Related Activities at PNL." Presented at the Infrastructure Modernization Implementation Committee Meeting, July 17, 1990, A buquerque, New Mexico.

\subsection{TEST PROCECURES}

The goal of this activity is to develop test procedures and take each procedure through a peer review and revision process that culminates with acceptance by an appropriate standards socjety (e.g., ASTM, the American Society of Heating, Refrigerating, and Air-Conditioning Engineers, Inc. [ASHRAE], the Institute of Electrica] and Electronics Engineers [IEEE]).

During the reporting period, two procedures were submitted for standards society consideration. Five procedures, not yet submitted for society consideration, underwent a Corps of Engineers review and are being updated and refined as experience is gained in field testing. One procedure is in the Corps of Engineers review process; seven additional procedures are in various stages of development. The following is the status of each of the MEL test procedures under development.

\subsubsection{Standards Society Ballot and Comment Process}

\section{\#1 Electrical End-Use Metering}

MEL Application Plan Development Guide (Appendix A to MEL Use Plan). 
6.2.2 Continuing Development with Review Completed

\#4 Measuring Lighting Levels

\#5 Ner Building Comissioning

\#6 Steam Distribution System Evaluation

\#7 Electrical Distribution System Evaluation

\#8 Boiler Efficiency Evaluation.

6.2.3 In Review Process at the Corps of Engineers

\#9 Building Heating, Ventilating and Air Conditioning System Evaluation.

6.2.4 Under DeveTopment or Being Drafted

\#3 Whole Building Performance Evaluation

\#10 Chiller Performance Testing

\#13 Electric Pump and Hotor Efficiency Testing

\#14 Electric Disturbance/Harmonics Analysis

\#17 Indoor Air Quality and Ventilation Measurement

\#18 Power Factor Determination

\#19 Substation Metering

\#20 Power Reliability Evaluation

\#21 Power Quality Evaluation

\#22 Distribution System Grounding.

6.2.5 Future Need--Not Yet Developed

\#11 Fuel Quality and Delivery Evaluation

\#15 Temperature Stratification Evaluation

\#16 Controller Evaluation

\#23 Hot and Chilled Water Distribution System Evaluation

\#24 Lighting Baseline Evaluation and Retrofit Verification. 


\subsection{INITIAL SITE VISIT REPORTS}

An Initial Site Visit Report is a new document developed during this reporting period and being implemented by PNL for MEL testing. It is prepared after PNL staff have visited a site to determine the appropriate testing activities at a site. Suggested tests are identified in the report, and those tests for FORSCOM sites are reviewed and approved by SAS prior to preparing the MAPs. A copy of the format of the report is given in Attachment 4 . Initial Site Visit Reports prepared during this reporting period are

- FTORD-SV1-90/04/07 Initial Site Visit for Ft. Ord

- FTRILEY-SVI-90/07/24 Initial Site Visit for Ft. Riley.

\subsection{MEL ASSIGNMENT PLANS}

MEL Assignment Plans (MAPs) are prepared by PNL for MEL testing. The following MAPs were prepared for FORSCOM sites during the reporting period:

Site MAP \# Test Description Date

Fort Ord

FTORD-001

FTORD-002

FTORD-003

FTORD-004

FTORD-005
Peak Demand at PX and Meter Calibration

Well Water Pump Electrical Demand

Electrical Distribution System Profile

Hospita] End-Use Characterization

Hospital Boiler Delivery Efficiency

Electrical Distribution System Profile

Chiller Delivery Efficiency

Chiller Load Determination
$06 / 90$

$06 / 90$

$06 / 90$

$06 / 90$

$06 / 90$

$08 / 90$

$08 / 90$

$08 / 90$

\subsection{TEST REPORTS}

Test reports are prepared after the testing activities described in the MAP are completed. The reports for FORSCOM testing are reviewed by SAS, revised (if necessary) by PNL, and then transmitted by SAS to the site as final reports. Additional revisions are made by PNL if comments are received by SAS from the site.

During the reporting period, four test reports were completed, reviewed, and transmitted to FORSCOM sites. These were

- Test Report CARSON-001-90/07/03 Building 8030 Lighting and End-Use Metering

- Test Report CARSON-002-90/06/18 Combustion Efficiency/Waste 0i7 Burn

- Test Report IRWIN-003-90/08/01 Heasured Lighting Levels in Four office Buildings 
- Test Report FTSAMH-001-90/02/12 Air Conditioner Controller Evaluation.

During the reporting period, three test reports were drafted and submitted to SAS for review. These were

- Test Report LEWIS-005-90/07/27 Conwissary Electric Profile

- Test Report FTMAC-001-90/07/26 Boiler Combustion/Delivery Efficiency

- Test Report FTMAC-003-90/08/22 Combustion Efficiency of 10 Small Boilers.

\subsection{OTHER DOCUMENTATION}

Other documentation prepared during this reporting period includes those papers and reports listed below:

- Parker, G. B. Energy Efficiency Testing Using the Mobile Energy Laboratory (MEL). PNL-SA-18194. Prepared for a newsletter to be distributed by the Savannah District Corps of Engineers (see Attachment 5).

- Proposed revisions to the MEL Use P7an for the semiannual MEL Use Committee Meeting in October in Chicago, 117 inois.

- Shankle, S. A. Utility Demand-Side Programs for FORSCOM Installations. Draft PNL report, July 1990.

- Secrest, T. J. Background Information for Lighting Technologies, Transformers, and Cogeneration Systems to Support Conservation Program Planning at Fort Lewis. PNL letter report to Fort Lewis DEH, June 12, 1990.

- Parker, G. B. , Heller, J., and Vasiloff, J. C.. Measurements for Energy-Efficiency Improvements Using the Mobile Energy Laboratories. Draft abstract for the MEL Use Committee review as an article to be submitted to The American Military Engineer journal. 


\subsection{PLANKED ACTIVITIES}

MEL-related activities planned for the period extending from October 1 , 1990, through April 30, 1991, are described in this section.

\subsection{FORSCOM PROJECT ACTIVITIES (PNL)}

- Initiate and complete winter testing at Fort Gillem for MAPs FTGIL001 and FTGIL-002.

- Install test equipment for FTORD-004 and FTORD-005.

- Revisit Fort Lewis to ascertain high-priority testing needed to support the resource/conservation acquisition evaluation project.

- Complete ongoing (remote) data collection activities at Fort Carson for CARSON-003 and at Fort MCPherson for FTMAC-002.

- Complete data analysis and prepare draft reports for CARSON-001, FSAMH-002, IRWIN-001, IRWIN-002, HUNTR-002, STHRT-001-RI, FTMAC002 , FTGIL-001, and FTGIL-002.

- Revisit Fort Carson to discusș base-wide energy metering and control system project with Steve Snyder.

- Complete first drafts of test procedures $\# 13,14,18$, and 19.

- Complete final drafts for standards society submission of test procedures \#9 and \#10.

- Finalize the Statement of Work for FY91 FORSCOM funding.

- Prepare feature article on MEL testing for publication in The American Military Engineer journa].

- Prepare the final report on utility demand-side offerings for FORSCOM installations.

- Initiate the resource/conservation acquisition process at a second FORSCOM site.

- Complete the rate analysis for Fort Ord.

\subsection{NEESA ACTIVITIES}

- Continue to evaluate cogeneration and thermal storage opportunities for selected Navy and Marine Corps bases.

- Begin to evaluate the potential for demand-side management opportunities at naval facilities. 
- Design plant and trunkline remote meters for NAEC Lakehurst, and install remote steam/electric meters at NADP Pensacola.

- Initiate a power quality analysis testing program.

\subsection{FEMP, DOD, AND FEDERAL AGENCIES ACTIVITIES}

- Organize and attend the MEL Use Committee Meeting in Chicago in October; prepare and distribute the minutes from that meeting.

- Prepare final proposed revisions to the MEL Use PIan, distribute the plan for review, approve the revisions, and publish a revised plan.

- Prepare agenda and make arrangements for the MEL Use Comnittee meeting in April 1991.

- Follow up on request for MEL testing from the U.S. Department of Transportation Urban Mass Transit Administration Region 5.

- Complete testing activities at the National Naval Medical Center and Merchant Marine Academy; prepare test reports for these two sites.

- Prepare a SOW and MAPs for testing at Lake City Army Ammunition Plant; initiate testing activities at the site; complete the test report for temperature measurements taken at the site.

- Continue to support the Hanford Energy Conservation Program and other Hanford testing and metering activities.

- Continue to work with Fort Lewis and the Tacoma Public Utilities to identify, fund, and implement energy conservation projects at the site. Begin to develop a testing and verification procedure for providing baseline information and for evaluating the projects.

- Assist the DOE in the preparation of an SES solicitation for the Forrestal Building, and develop a testing procedure to evaluate proposed lighting and control retrofits. 


\subsection{SCHEDULE}

Below is the PNL schedule for MEL activities during the reporting period.

\section{MOBILE ENERGY LABORATORY SCHEDULE FOR} THE FEDERAL ENERGY MANAGEMENT PROGRAM

\begin{tabular}{|l|l|l|l|}
\hline $\begin{array}{l}\text { USING } \\
\text { AGENCY }\end{array}$ & DATE & $\begin{array}{l}\text { COMP. } \\
\text { DATE }\end{array}$ & ITEM \\
DESCRIPTION \\
\hline
\end{tabular}

BUS/EQUIPMENT ACTIVITY: DOE -RFS 03/30-04/24 ARMY-RFS $07 / 30 / 90$

062990 071690

FY90 TEST EQUIPMENT PURCHASE SPECIFICATNS REPAIR AND REMOVE BUS FROM FT CARSON

ON-SITE ACTIVITY

$\begin{array}{ll}\text { ARMY-PRA } & 12 / 15-07 / 30 \\ \text { ARMY-RFS } & 01 / 29-07 / 08 \\ \text { ARMY-RFS } & 01 / 29-04 / 08 \\ \text { ARMY-PRA } & 01 / 29-08 / 30 \\ \text { ARMY-RFS } & 06 / 25-06 / 29 \\ \text { ARMY-RFS } & 01 / 29-08 / 30 \\ \text { ARMY-RFS } & 02 / 19-03 / 01 \\ \text { ARMY-RFS } & 02 / 19-03 / 01 \\ \text { NAVY-RFS } & 03 / 15-04 / 10 \\ \text { NAVY-RFS } & 03 / 15-08 / 30 \\ \text { ARMY-PRA } & 03 / 26-03 / 30 \\ \text { DOT -RPM } & 05 / 01-05 / 02 \\ \text { OOE -RPM } & 05 / 14-06 / 07 \\ \text { ARMY-RFS } & 06 / 04-06 / 15 \\ \text { ARMY-RFS } & 06 / 05-08 / 31 \\ \text { ARMY-GBP } & 08 / 29-08 / 30 \\ \text { DOT -RPM } & 08 / 30-09 / 30\end{array}$

MAPS/REPORTS:
ARMY-GBP
ARMY-GBP
$A R M Y-G B P$
ARMY -GBP
$A R M Y-G B P$
$A R M Y-G B P$
$A R M Y-G B P$
ARMY -GBP
ARMY - GBP
$A R M Y-G B P$
ARMY - GBP
ARMY -GBP
ARMY-GBP
ARMY - PRA
ARMY - PRA
ARMY-PRA

\section{FT IRWIN TESTS}

FT MCPHERSON TESTS

040190 FT GILLEM TESTS

FT STEWART TESTS

092390 HUNTER AIR FIELD TEST EQUIPMENT INSTALL \#2 HUNTER AIR FIELD TESTS

FT LEWIS WINTER TEST EQUIPMENT INSTALL.

FT LEWIS WINTER TESTS

041090 NNMC TEST EQUIPMENT INSTALLATION

NNMC TESTS

041290 FT ORD SITE VIS1T

050290 MERCHANT MARINE ACADEMY TEST \#1

FORRESTAL BUILDING TESTS

FT SAM HOUSTON TEST EQUIPMENT INSTALLATION FT SAM HOUSTON TESTS

083090 LAKE CITY AAP SITE VISIT/PRELIMINARY TESTS MERCHANT MARINE ACADEMY TEST \#2

\section{LEWIS-002 TEST REPORT}

041690 FT ORD INITIAL SITE VISIT REPORT

LEWIS-003 TEST REPORT

LEWIS-005 TEST REPORT

CARSON-001 TEST REPORT

CARSON-002 TEST REPORT

FTMAC-001 TEST REPORT

FTMAC-002 TEST REPORT

FTMAC-003 TEST REPORT

FT RILEY INITIAL SITE VISIT REPORT

IRHIN-001 TEST REPORT

IRHIN-002 TEST REPORT

082490 FT RILEY MAPS PREPARED

STHRT-001 TEST REPORT

STHRT-0021 TEST REPORT

FTSAMH-002 TEST REPORT 
SCHEDULE (Cont.)

\begin{tabular}{|c|c|c|c|}
\hline $\begin{array}{l}\text { USING } \\
\text { AGENCY }\end{array}$ & DATE & $\begin{array}{l}\text { COMP. } \\
\text { DATE }\end{array}$ & $\begin{array}{l}\text { ITEM } \\
\text { DESCRIPTION }\end{array}$ \\
\hline $\begin{array}{l}\text { PROCEDURES } \\
\text { ARMY-DLH } \\
\text { ARMY-DLH } \\
\text { ARMY-DLH } \\
\text { ARMY-DLH } \\
\text { ARMY-DLH } \\
\text { ARMY-DLH } \\
\text { ARMY-DLH } \\
\text { ARMY-DLH } \\
\text { ARMY-DLH }\end{array}$ & $\begin{array}{l}123089 \\
030190 \\
063090 \\
071590 \\
073090 \\
083090 \\
093090 \\
113090 \\
093090\end{array}$ & 083090 & $\begin{array}{l}\text { WHOLE BUILDING TEST PROCEDURE DRAFT } \\
\text { CHILLER TESTING PROCEDURE DRAFT } \\
\text { INCORPORATE SAS COMMENTS INTO PROCEDURES } \\
\text { HOT AND COLD WATER DIST. SYS. PROC. DRAFT } \\
\text { ELECTRIC MOTOR EFFICIENCY TEST PROC. DRAFT } \\
\text { POWER FACTOR DETERMINATION PROC. DRAFT } \\
\text { TEMP. STRATIFICATION EVAL. PROC. DRAFT } \\
\text { ELEC. DISTURB, AND HARMONICS ANAL. DRAFT } \\
\text { PREPARE PROCEEURE, \#1 FOR ASTM BALLOT/REVIEW }\end{array}$ \\
\hline $\begin{array}{l}\text { OTHER: } \\
\text { DOE -RPM } \\
\text { DOE -RPM } \\
\text { DOE -JWC } \\
\text { DOE -RPM } \\
\text { ARMY-WOP } \\
\text { DOE -JCV }\end{array}$ & $\begin{array}{c}050190 \\
04 / 03-04 / 04 \\
04 / 17-04 / 19 \\
051090 \\
05 / 15-05 / 16 \\
09 / 25-09 / 27\end{array}$ & $\begin{array}{l}033090 \\
041990 \\
051090 \\
051690 \\
092790\end{array}$ & $\begin{array}{l}\text { CHILLER EVALUATION CAPABILITY BRIEF } \\
\text { MEL USER COMMITTEE MEETING IN SAN DIEGO } \\
\text { CENET MEETING PRESENTATION } \\
\text { S.A.M.E. MEETING IN DAYTON } \\
\text { FORSCOM ENERGY PROGRAM SEMIANNUAL REVIEW } \\
\text { FORSCOM FEDS/MEL REVIEW AT PNL }\end{array}$ \\
\hline
\end{tabular}


ATTACHMENT 1

MEL USE COMMITTEE MEeting MINUTES

MARCH 29-30, 1990, SAN DIEG0, CALIFORNIA 


\section{MINUTES}

\section{HOBILE ENERGY LABORATORY USE COMAITTEE MEETING MARCH 29-30, 1990 SAN DIEGO, CALIFORNIA}

At approximately 1300 hours on March 29, 1990 the Mobile Energy Laboratory Use Committee Meeting was called to order at the Ramada Hotel in San Diego, California. The agenda for the meeting is provided in Attachment 1 . The following individuals were in attendance:

K. Dean DeVine - DOE FEMP, MEL Use Committee Chairman

Rich Mazzucchi - PNL, MEL Use Committee Executive Secretary

Jim Vasitoff - FORSCOM, U.S. Army MEL Use Committee Representative

Bill Riches - FERMI Labs, Other Federal Agency MEL Use Committee Representative

Gary DeVeny - U.S. Air Force Logistics Command

Rick Messock - Navy Energy and Environmental Support Activity

Jim Heller - U.S. Navy MEL Use Committee Representative

Rich Szydlowski - PNL, MEL Technical Coordinator

Graham Parker - PNL, MEL Project Manager

Mr. Michael Santoro, U.S. Air Force MEL Use Committee Representative, was not in attendance. However, with four voting members a quorum existed and official business was conducted. The meeting was adjourned at approximately 1600 hours on March 30, 1990. The next meeting is scheduled on 0ctober 30 and 31,1990 in Chicago, IL.

Eleven action item/decisions from the meeting are described in these meeting minutes. Significant action items are identified in Table 1. The table identifies the person(s) having action responsibility and the anticipated action completion date. If your name appears in this table be sure to carefully read the item description and take the appropriate action. Questions or clarifications of these minutes should be directed to the executive secretary (509) 375-3606 during regular business hours PST. 
Table 1: MEL Use Comittee Action Items

$\begin{array}{lll}\text { Item Action } & \text { Action } & \text { Action Item Title } \\ \text { Persons } & \text { Date } & \end{array}$

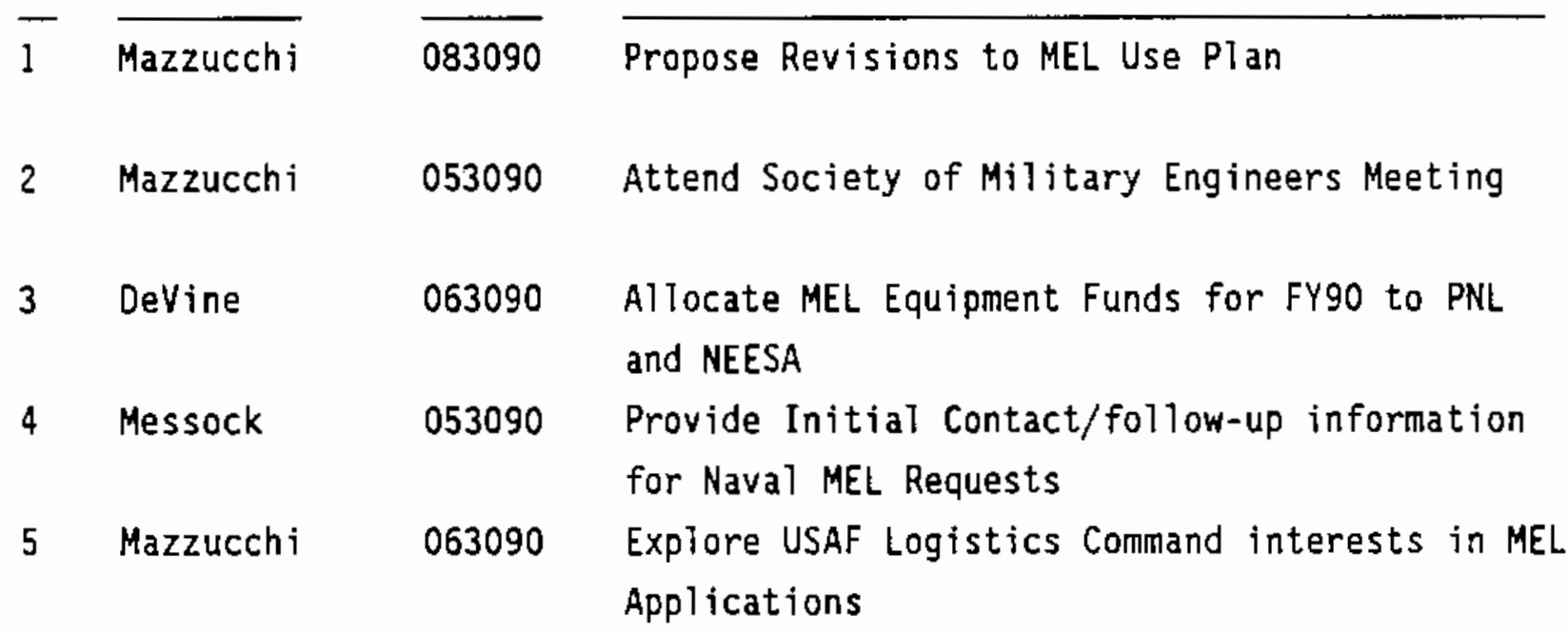

6 DeVine 083090 Determine MEL policy pertaining to non-federal agency applications

7 Szydlowski $063090 \quad$ Finalize 1 isting of MEL equipment additions Parker

8 Messock 093090 Procure and deliver MEL equipment to PNL

9 Riches 093090 Explore interests of Federal Urban Mass Transit Authority in MEL Applications

10 Parker 093090 Prepare MEL Applications Article

11 Mazzucchi 073090 Prepare MEL Semi-annual Report

11 a Parker 043090 Prepare FORSCOM/MEL Semi-annual Report

The first item was to introduce the attendees and to provide background regarding the purpose and schedule of the meeting. The meeting was attended by Mr. Gary DeVeny of the USAF Logistics Command. Aithough he was not 
authorized to participate in an official capacity, he was able to represent USAF interests in the MEL program and to gather useful information to facilitate USAF applications. Mr. Jim Helier of NEESA was identified by Rick Messock and the new Navy MEL Use Committee representative pending approva] by the Committee.

The first item of business was to approve the Committee Meeting Minutes from Atlanta GA. These were approved with the correction of Mr. Messock's first name to read Rick rather than $B i 11$.

The next item of discussion was revisions to the MEL Committee Charter and Use Plan. Draft revisions were distributed to the members prior to the meeting, however approval sheets from the Navy had not been received. A new section proposed for the MEL Use Plan was distributed entitied "Safety Operation Plan". The Executive Secretary was instructed to add this section and make other revisions that have been approved and produce a subsequent revision prior to the next meeting so that it could be approved as revised. See Action Item 1 below.

Rick Messock of the Navy presented some background of NEESA involvement with the MEL and discussed current and planned Navy applications. This material set the stage for discussions of the MEL Brochure and possible inquiries from Navy activities. See Action Item 4 below.

Following a break the committee discussed MEL equipment issues. Rich Szydlowski presented PNL concerns and reservations regarding the procurement of new equipment through NEESA. Confusion exists regarding the amount of funding NEESA has for equipment purchases, the timeliness of NEESA procurement for PNL, and inventory control issues. See Action Item 8 below.

The strategy for USAF applications of the MEL were discussed next. The Logistics Command had expressed interest and sent $\mathrm{Mr}$. DeVeny to attend the MEL Use Committee meeting to get more information. The Executive Secretary was directed to provide examples of MEL products and background material to Mr DeVeny for follow-up action. See Action Item 5 below. 
At the beginning of the second meeting day, Graham Parker updated the committee with respect to the status of MEL applications and procedure development. Five test procedure drafts have been completed and are presently being reviewed by the Corps of Engineers and others. Two more are being prepared currently, and five others are planned for the near future. The status of MAPs and Reports is summarized in Attachment 2.

Rich Szydlowski summarized Army MEL Applications and presented selected test results. This material is available on request and displays the electrical energy reductions achieved in buildings at $\mathrm{Ft}$. Carson, boiler efficiency tests at Ft. McPherson, and whole building electrical metering at an office/administrative building at Ft. Irwin. These and other MEL applications are 1isted in Attachment 3, the MEL Suspense Schedule. The executive secretary was instructed to produce a Semi-Annual MEL Report describing the MEL activities. See Action Item 11 below.

Following a break, Rick Messock summarized U.S. Navy MEL Applications. These are summarized in attachment 4 . Next Bill Riches distributed a letter from the Urban Mass Transportation Administration providing some background and requesting information as to how to coordinate MEL applications. A copy of this letter is provided as attachment 5 . This discussion resulted in Action Items 6 and 9 below.

After lunch, Rich Szydlowski lead a discussion of MEL equipment and capability enhancements. He was not prepared to distribute an itemized and prioritized listing of MEL enhancements because of the uncertainties surrounding the current status of prior requests from NEESA and the funds available for equipment procurement. He did however describe the types of equipment desired and general price information for committee consideration. NEESA aiso provided information on the "core" MEL equipment. Funding was clarified to include \$42K presently at NEESA, and \$37.5K forthcoming to PNL for future procurements this fiscal year. Based upon this information Rich was directed to prepare a prioritized listing of equipment needs. See Action Item 7 below. 
Next Rich Mazzucchi discussed the MEL Brochures and Technology Transfer Efforts. The Navy expressed concern regarding how this would be received by Naval activities and how follow-up would be coordinated. They do not intend to use the brochures for their outreach efforts as other means are available to them. Rick Messock agreed to provide appropriate language for PNL staff to use when responding to MEL requests from Navy activities. See action item 4 below.

Mr. Mazzucchi next discussed the value of test reports and the Semi-Annual MEL Report to follow-up on initial inquiries for MEL services. Most potential users want specifics regarding what they can expect in terms of costs and benefits. See Action Item 11 below.

Graham Parker discussed the merits of a semi-technical article for publication in a professional periodical such as The Military Engineer. He was directed to produce a report sumnarizing Army MEL applications to lead this activity. See Action Item 10 below.

The final topics of discussion were organization issues. The Executive Secretary reiterated the problems of getting the USAF to take a more active role in the program, and $B i 11$ Riches expressed concern regarding how to approach other federal agencies. The possibility of providing complementary initial site visits and MAPs for selected sites to "prime the pump" was discussed, however such efforts can not begin until next fiscal year due current FEMP funding limitations.

Another issue surrounds the status and maintenance of the MEL busses. It was agreed that the Navy would continue management of their MEL bus and that PNL would maintain/deactivate the remaining 3 MELs. PNL will develop specific recommendations for the deactivation of the busses for discussion at the next MEL Use Committee meeting. The meeting was adjourned following a review of the action items oeveloped from this meeting.

Each action item is described below. Please see Table 1 for the listing of the responsible individuals and milestones.

5 of 8 pages.

MELMIN.SD August 19,1990 
Action Item 1: Revisions of the MEL Use Plan. The MEL Use Plan (PNL-6867) needs to be revised to reflect current operations. Considering the extent of these changes, the committee directed that a completely new document be prepared and distributed, with the changes highlighted to facilitate approval. Deleted material will be placed within brackets, while new material will appear in bold face print. This material will be distributed to the voting members of the committee sixty days in advance of the next schedule committee meeting.

Action Item 2: Society of Military Engineers Heeting. The executive secretary will attended the Society of Military Engineers Annual Meeting in Dayton Ohio to become famitiarized with the organization and discuss MEL activities as appropriate. Attendance costs should be low because travel will be in conjunction with other requirements. This trip will also permit the secretary to follow-up on material delivered to the USAF Logistics Command headquartered in Dayton.

Action Item 3: MEL Equipment Funds for FY90. It was agreed that funds for MEL equipment for FY90 and beyond would be allocated according to a formula of $75 \%$ to PNL, and $25 \%$ to NEESA. This will permit NEESA to maintain the inventory of equipment for Naval applications and PNL to handle the other agency needs. NEESA and PNL will share equipment when needs dictate and availability permits. Accordingly FEMP will transfer $\$ 37.5 \mathrm{~K}$ of FY90 funds to PNL and $\$ 12.5 \mathrm{~K}$ to NEESA. NEESA reported that approximately $\$ 42 \mathrm{~K}$ of equipment funding remained from previous FEMP allocations which will be used to procure equipment as specified by PNL.

Action Item 4: Initial Contact/Follow Up Information for Navy MEL Requests. NEESA is to develop specific language for PNL to use in initial discussion with Navy activities. This is to minimize confusion on the part of Navy activities with regard to how to acquire MEL services that may result from widespread distribution of the MEL brochure or other material.

Action Item 5: USAF Logistics Command Interests in MEL Applications. The executive secretary was directed to send explanatory material to the Gary Deveny of the USAF Logistics Command and to follow up on the initial 
expression of interest. Efforts will continue to interest particular USAF installations in funding MEL services at their sites.

Action Item 6: MEL Policy Pertaining to Non-federal Agencies. A request for information on possible MEL applications by the Urban Transit Authority was received by $B i l l$ Riches and discussed with the committee. This quasigovernment agency is responsible for mass transit facilities and is funded in large part by federal grants. FEMP needs to provide guidance with regard to if and how to respond to such requests, and develop a policy to ensure that federal agency requirements are not unduly jeopardized.

Action Item 7: Listing of MEL Equipment Additions. With the resolution of presently available and FY90 funding for MEL equipment, PNL was directed to develop a unified and prioritized listing of new MEL equipment needs. This will supplement the equipment previously on order through NEESA.

Action Item 8: Procure and Deliver Equipment to PNL. NEESA was directed to expeditiously procure MEL equipment previously requested by PNL as well as additional equipment identified in Item 7 above. In the future PNL will acquire equipment directly as funds come into the PNL system.

Action Item 9: Urban Transportation Administration MEL Applications. Mr. Riches will pursue MEL applications for the quasi-government agency once policy guidance is provided by FEMP and availability and cost of service information is provided by PNL.

Action Item 10: MEL Applications Article. An article will be prepared for the "Military Engineer" magazine by Graham Parker to describe the MEL applications underway for the U.S. Army and to summarize results. This article may also be submitted to other periodicals for publication.

Action Item 11: Prepare MEL Semi-Annual Report. The semi-annual report of MEL applications and developments will be produced by the Executive Secretary for review by the committee prior to the next meeting. After a draft is provided to the committee it will be released as a formal PNL document. 
Action Item 1la: Prepare FORSCOM/MEL Semi-Annual Report. A semi-annual report of MEL Applications for FORSCOM will be prepared and distributed to the U.S. Army and FEMP Representative to document MEL activities in this area. This report will form the basis for the MEL seni-annual report. 


\section{Attachment 1}

\section{AGENDA FOR SAN DIEGO MEETING}




\section{MOHIIE ENERGY IABCRATORY CSE COMIITISE \\ SFRIIG 1990 MEEITIE \\ DRAFT ACBNDA}

PLACE: DOWNIOWN RAMADA INN OF SAN DIEGO CAIIIFORNIA, $660 \mathrm{~K}$ SIREET, BOARD ROCM THURSDAY MARCH 29, 1990

11:30AM IUNCH AT HOTEL, RESTIURANT (OPITONAL)

1:00PM MEETING BEGDS, INIRODUCTIONS AND BACKGROUND

1:15RM ACTION TIEM REVIEN AND APLPOVAL OF MINUTES FROM ATLANIA MEETING

2:00PM MEL USE PIAN AND COMITIIEE CGARLER REVISIONS

3:OOFM EREAK

3:30RM MEI EQUIMMENT AND NEESA COORDINATION

4:15FM USAF/AFESC MEL APPLICATION STRAIEGY

5: OOPM ADTORRN

6:00PM DTRER - LOCATION TO BE DELERMINED

FRIDAY MARCH 30, 1990

7:30AM BREAKFAST AT HOTEL (OPIIONAL)

8:30AM OVERVIEW OF MEI APPLICATIONS AND FROCEDORE DEVEIOEMLNIS

9:00AM ARMY MEL APPITCATIONS

10:30AM BREAK

11:0QAM U.S. NAVY MEL APPIICATIONS

11:30AM OTHER MEL APPLICATIONS

12:00 IINCH

1:30PM MEL EQUIPMENT AND CAPABILITY ENTANCEMENTS

2:30RM MEL EROCHURES AND TECHNOLOGY TRANSFER EFFORIS

3:30RM ORGANIZATTONAL ISSUES

4:00RM ADTOURN

5:30RM ENTERTAINMENT AND DINRER - TED 


\section{Attachment 2}

MEL PROCEDURES, REPORTS, AND APPLICATION PLAN STATUS 
HAP

FORT CARSON

-
-
-

TEST UESCRIPTION

[Site Visit 01/89]

Waste 0il Burn Evaluation

Building 8030 Metering (Lighting)

Combustion Efficiency Test

Building 8000 Metering (Compressor)
STATUS

Testing Completed 03/89

Testing Started 03/89

Testing Compieted 03/89

Testing Started 03/89

FT LEWIS [site Visit 05/89]

$\begin{array}{ll}\text { FTLEWIS-001 } & \text { Power Factor at Yaktma Firing Range } \\ \text { FTLEHIS-002 } & \text { Elect. Distributin System Pritile } \\ \text { FTLEHIS-003 } & \text { Sewage Treatment Plant Profile } \\ \text { FTLEHIS-004 } & \text { Lighting Levels in 8uilding } \\ \text { FTLEWIS-005 } & \text { Commissary Electric Profile } \\ \text { FTLEWIS-005-R1 Steam \& HTHW Boiler Testing } \\ \text { FTLEWIS-007 } & \text { Barracks Heat Demand } \\ \text { FTLEHIS-008 } & \text { Helicopter Hanger Retrofit Evaluation }\end{array}$

FORT SAM HOUSTON [Site Visit 08/89]

FSAMH-001

FSAMH -002

FSAMH -003

FSAMH -00.4

FORT IRHIN

IRWIN-OOI

IRWIN-002

IRWIN-OC 3
AC Control System Fvaluation

Chiller Performance Testing

Hot Water Controller Evaluation

Laundry Boiler Efficiency

[Site Visit 09/89]

Elec, Oistribution System Profile Ofice Building Elect. Use Profile office Building Lighting Levels
Unsigned by $\mathrm{OEH}$

Testing Completed $: 0 / 89$

Testing Completed $06 / 89$

Unsigned by $\mathrm{OEH}$

Testing Completed :0/89

Testing to Start. oif $01 / 91$

Testing to Start -92 -90 $01 / 91$ Unsigned by OEH

HUNTER ARMY AIR FIELD [Site visit 10/89]

HUNTR-001 Elec. Distribution System Proile

HUNTR-002 Chilier Periomance Evaluation

Test Equip. Inst. 02/90

Testing to Siart $07 / 90$

FORT STEGART [SitE Visit 10/89]

STWRT-001-R1 Elec. Distribution System Profile

STIHRT-002-R1 ilain Power Plant Elec. Profile

Testing Completed 08/89

Testing to Start $07 / 90$

Testing to $5 \mathrm{itart} 02 / 90$

Testing to Start $02 / 90$

Test Equip. Inst. $12 / 89$

Test Equip. Inst. $12 / 89$

Testing Completed $12 / 89$

FORT HCPHERSOM [SIte VIsit 11/89]

FTMAC-001 Combutsion Efficiency 2 Boilers

FTMAC-002 Building 200 Elec. Profile

FTHAC-003 Combutions Efficiency 5mall Boilers

Test Equip. Inst. 02/00

Test Equip. Inst. 02/00

Testing Compteted 02/90

Test Equip. Inst. 02/90

Testing 
FORT GILLEM [Site Visit 11/89]

FTGIL-001

FTGIL-002
Temp. Stratification in Warehouses

Boiler Shutdown Evaluation

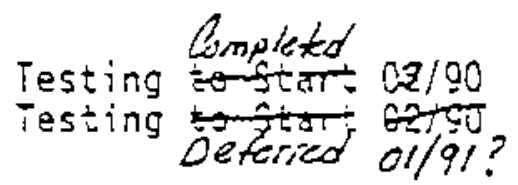




\begin{tabular}{|c|c|c|}
\hline \multirow{2}{*}{\multicolumn{3}{|c|}{$\begin{array}{l}\text { MAP }: \\
\text { FORT CARSON }\end{array}$}} \\
\hline & & \\
\hline & $\begin{array}{l}\text { Waste 0il Gurn Evaluation } \\
\text { Building } 8030 \text { Metering (Lighting) } \\
\text { Combustion Efficiency Test } \\
\text { Building } 8000 \text { Metering (Compressor) }\end{array}$ & $\begin{array}{l}\text { Oraft Completed } 04 / 89 \\
\text { Testing Started 03/89 } \\
\text { Data Compiled 04/89 } \\
\text { Testing Started 03/89 }\end{array}$ \\
\hline
\end{tabular}

FORT LEHIS

FTLEWIS-002 Elect. Distributin System Profile

FTLEHIS-003 Sewage Treatment Plant Profile

FTLEWIS-005 Comanissary Electric Profile

FTLEHIS-006-RI Steam \& HTHW Boiler Testing

FTLEWIS-007 Barracks Heat Demand

Data Taken/Summarized

Data Taken/Summerized

Data Taken/Summarized
Testing to Star: 0ztso $01 / 91$

Testing to Star: Getgo ol/91

FORT SAM HOUSTON

SAMH 001

FSAMH -002

FSAMH -003

FSAMH -004

FORT IRHIN

IRH IN-OOI

IRHIN-002

IRHIN-003
AC Control System Evaiuation

Chiller Perfomance Testing

Hot Water Controller Evaluation

Laundry Boiler Efficiency

Elec. Distribution System Profile Office Building Elec:. Use Profile Office Building Lighting Levels

HUNTER ARMY AIR FIELD

HUNTR-001

HUNTR-002

Elec. Distribution System Profile Chiller Performance Evaiuation

\section{FORT STEHART}

STHRT -001-R1 STHRT-002-R1

Elec. Distribution System Profile Main Power Plant Elec. Profile

FOR MCRHERSON

FTMAC -001

FTMAC -002

FTMAC-003

FORT GHLEM

FTGIL-001

FTGIL-002
Combutsion Efficiency 2 Boilers

Building 200 Elec. Profile

Combutions Efficiency Small Boilers

Temp. Stratification in Warehouses Boiler Shutdown Evaluation
Draft Completed 08/89

Testing to Stari $07 / 90$

Testing to Start $02 / 90$

Testing to Start $02 / 90$

Test Equip. Inst. 12/89

Test Equip. Inst. 12/89 Completed $12 / 89$

Test Equip. Inst. 02/90 Testing to Start: 07/90

Test Equig. Ins:. $02 / 90$

Test Equip. Inst. 02/90

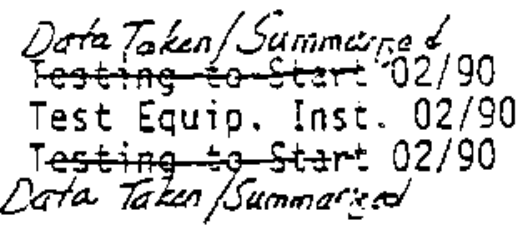

Testing Completel 02/90

Testing thistre 02490 Detered 01/91? 
Attachment 3

\section{MEL SUSPENSE SCHEDULE}


MOBILE ENERGY LABORATORY SUSPENSE SCHEDULE FOR THE FEDERAL ENERGY MANAGEMENT PROGRAM
LAST UPDATE: 081590 CONFIRMATION DATE: 101590

Note: Only dates prior to the confirmation date are firm.

\begin{tabular}{|c|c|c|c|}
\hline $\begin{array}{l}\text { USING } \\
\text { AGENCY }\end{array}$ & $\begin{array}{l}\text { SUSP. } \\
\text { DATE }\end{array}$ & $\begin{array}{l}\text { COMP. } \\
\text { DATE }\end{array}$ & $\begin{array}{l}\text { ITEM } \\
\text { DESCRIPTION }\end{array}$ \\
\hline 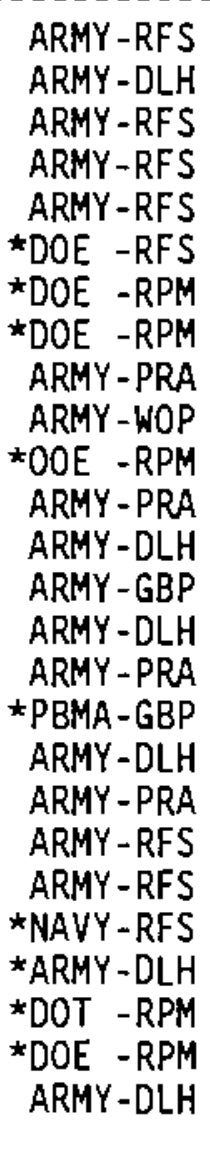 & $\begin{array}{l}021890 \\
030190 \\
031889 \\
032089 \\
040890 \\
042090 \\
050190 \\
051090 \\
051590 \\
051690 \\
060790 \\
062990 \\
071590 \\
072090 \\
073090 \\
073090 \\
083090 \\
083090 \\
083090 \\
083090 \\
083190 \\
083090 \\
093090 \\
093090 \\
103190 \\
113090\end{array}$ & $\begin{array}{l}051090 \\
060890 \\
051690 \\
060790 \\
071390 \\
072490\end{array}$ & $\begin{array}{l}\text { ARMY MEL MOVED TO FT. LEWIS } \\
\text { CHILLER TESTING AT PNL \& DRAFT PROCEDURE } \\
\text { FT LEWIS WINTER TESTS } \\
\text { FT SAM HOUSTON WINTER TESTS } \\
\text { FT MCPHERSON TESTS } \\
\text { NEW TEST EQUIPMENT SPECIFICATIONS PREPARED } \\
\text { CHILLER EVALUATION CAPABILITY BRIEF } \\
\text { S.A.M.E. MEL PRESENTATION } \\
\text { FT ORD MAPS PREPARED } \\
\text { FORSCOM ENERGY PROGRAM SEMI-ANNUAL REVIEW } \\
\text { FORRESTAL BUILDING TESTS } \\
\text { FT RILEY INITIAL SITE VISIT } \\
\text { HOT AND COLD WATER DIST. SYS, PROC. ORAFT } \\
\text { FT RILEY INITIAL SITE VISIT REPORT } \\
\text { ELECTRIC MOTOR EFFICIENCY TEST PROC. ORAFT } \\
\text { FT IRWIN TESTS } \\
\text { LAKE CITY AAP SITE VISIT/PRELIMINARY TESTS } \\
\text { POWER FACTOR DETERMINATION PROCEDURE ORAFT } \\
\text { FT STEWART TESTS } \\
\text { HUNTER ARMY AIR FIELD TESTS } \\
\text { FT SAM HOUSTON SUMMER TESTS } \\
\text { NATIONAL NAVAL MEDICAL CENTER TESTS } \\
\text { TEMPERATURE STRATIFICATION EVAL. PROC. DRAFT } \\
\text { MERCHANT MARINE ACADEMY TESTS } \\
\text { MEL USE COMMITTEE MEETING } \\
\text { ELEC. OISTURB. AND HARMONICS ANAL. PROC. } \\
\text { DRAFT }\end{array}$ \\
\hline
\end{tabular}

* MEL-related activities not funded by FORSCOM 
MOBILE ENERGY LABORATORY SUSPENSE SCHEDULE (DETAIL) LAST UPDATE: 081590 FOR THE FEDERAL ENERGY MANAGEMENT PROGRAM CONFIRMATION DATE: 101590

Note: Only dates prior to the confirmation date are firm.

\begin{tabular}{|c|c|c|c|}
\hline $\begin{array}{l}\text { USING } \\
\text { AGENCY }\end{array}$ & DATE & $\begin{array}{l}\text { COMP. } \\
\text { DATE }\end{array}$ & $\begin{array}{l}\text { ITEM } \\
\text { DESCRIPTION }\end{array}$ \\
\hline $\begin{array}{l}\text { L BUS/EQUIP } \\
\text { ARMY-RFS } \\
\star \text { DOE - RFS }\end{array}$ & $\begin{array}{c}\text { AENT ACTIVITY } \\
02 / 18-02 / 18 \\
03 / 30-04 / 20\end{array}$ & 062990 & $\begin{array}{l}\text { ARMY MEL MOVED TO FT. LEWIS } \\
\text { FY9O TEST EQUIPMENT PURCHASE }\end{array}$ \\
\hline $\begin{array}{l}\text { ECIF ICATION } \\
\text { ARMY-RFS }\end{array}$ & $07 / 30 / 90$ & 071690 & REPAIR AND REMOVE BUS FROM FT. CARSON \\
\hline $\begin{array}{c}\text { ON-SITE ACTIV } \\
\text { ARMY-PRA } \\
\text { ARMY-RFS } \\
\text { ARMY-RFS } \\
\text { ARMY-RFS } \\
\text { ARMY-PRA } \\
\text { ARMY-RFS } \\
\text { ARMY -RFS } \\
\text { ARMY-RFS } \\
\text { ARMY-RFS } \\
\text { •NAVY-RFS }\end{array}$ & $\begin{array}{l}\text { ITY: } \\
12 / 15-07 / 30 \\
01 / 29-01 / 29 \\
01 / 29-02 / 10 \\
01 / 29-04 / 08 \\
01 / 29-08 / 30 \\
06 / 25-06 / 29 \\
01 / 29-08 / 30 \\
02 / 19-03 / 01 \\
02 / 19-03 / 01 \\
03 / 15-08 / 30\end{array}$ & 021090 & $\begin{array}{l}\text { FT IRWIN TESTS } \\
\text { REMOVE TEST EQUIPMENT FROM FT CARSON } \\
\text { FT MCPHERSON TEST EQUIPMENT INSTALLATION } \\
\text { FT MCPHERSON TESTS } \\
\text { FT STEWART TESTS } \\
\text { HUNTER AIR FIELD TEST EQUIPMENT INSTALL } \\
\text { HUNTER AIR FIELD TESTS } \\
\text { FT LEWIS WINTER TEST EQUIPMENT INSTALL. } \\
\text { FT LEWIS WINTER TESTS } \\
\text { NNMC TESTS }\end{array}$ \\
\hline $\begin{array}{c}\text { *DOT }- \text { RPM } \\
\text { *DOE - RPM } \\
\text { ARMY-RFS }\end{array}$ & $\begin{array}{l}05 / 01-05 / 02 \\
05 / 14-06 / 07 \\
06 / 04-06 / 15\end{array}$ & $\begin{array}{l}050990 \\
060790\end{array}$ & $\begin{array}{l}\text { MERCHANT MARINE ACADEMY TEST \#1 } \\
\text { FORRESTAL BUILDING TESTS } \\
\text { FT SAM HOUSTON SUMMER TEST EQUIP. } \\
\text { INSTALL. }\end{array}$ \\
\hline $\begin{array}{l}\text { ARMY-PRA } \\
\text { ARMY-RFS } \\
\text { *PBMA-GBP }\end{array}$ & $\begin{array}{l}06 / 25-06 / 29 \\
06 / 05-08 / 31 \\
08 / 29-08 / 30\end{array}$ & 071390 & $\begin{array}{l}\text { FT RILEY SITE VISIT } \\
\text { FT SAM HOUSTON SUMMER TESTS } \\
\text { LAKE CITY AAP SITE VISIT/PRELIMINARY } \\
\text { TESTS }\end{array}$ \\
\hline${ }^{\star} D O T-R P M$ & $08 / 30-09 / 30$ & & MERCHANT MARINE ACADEMY TEST \#2 \\
\hline $\begin{array}{l}\text { APS/REPORTS: } \\
\text { ARMY-GBP } \\
\text { ARMY-GBP } \\
\text { ARMY-GBP } \\
\text { ARMY-GBP } \\
\text { ARMY-GBP } \\
\text { ARMY-GBP } \\
\text { ARMY-GBP }\end{array}$ & $\begin{array}{l}01 / 15-01 / 29 \\
02 / 19-03 / 01 \\
03 / 15-05 / 01 \\
05 / 29-06 / 05 \\
07 / 16-07 / 20 \\
07 / 16-09 / 01 \\
08 / 01-10 / 01\end{array}$ & $\begin{array}{l}060590 \\
072490\end{array}$ & $\begin{array}{l}\text { FTLEWIS-002,-003,-005 TEST REPORTS } \\
\text { FT CARSON-001, -002, -003 TEST REPORTS } \\
\text { FTMAC-001, -002, -003 TEST REPORTS } \\
\text { FT ORD MAPS PREPARED } \\
\text { FT RILEY INITIAL SITE VISIT REPORT } \\
\text { IRWIN-001 TEST REPORT } \\
\text { IRWIN-002 TEST REPORT }\end{array}$ \\
\hline
\end{tabular}


MOBILE ENERGY LABORATORY SUSPENSE SCHEDULE (DETAIL) LAST UPDATE: 081590 FOR THE FEDERAL ENERGY MANAGEMENT PROGRAM CONFIRMATION DATE: 101590 Note: Only dates prior to the confirmation date are firm.

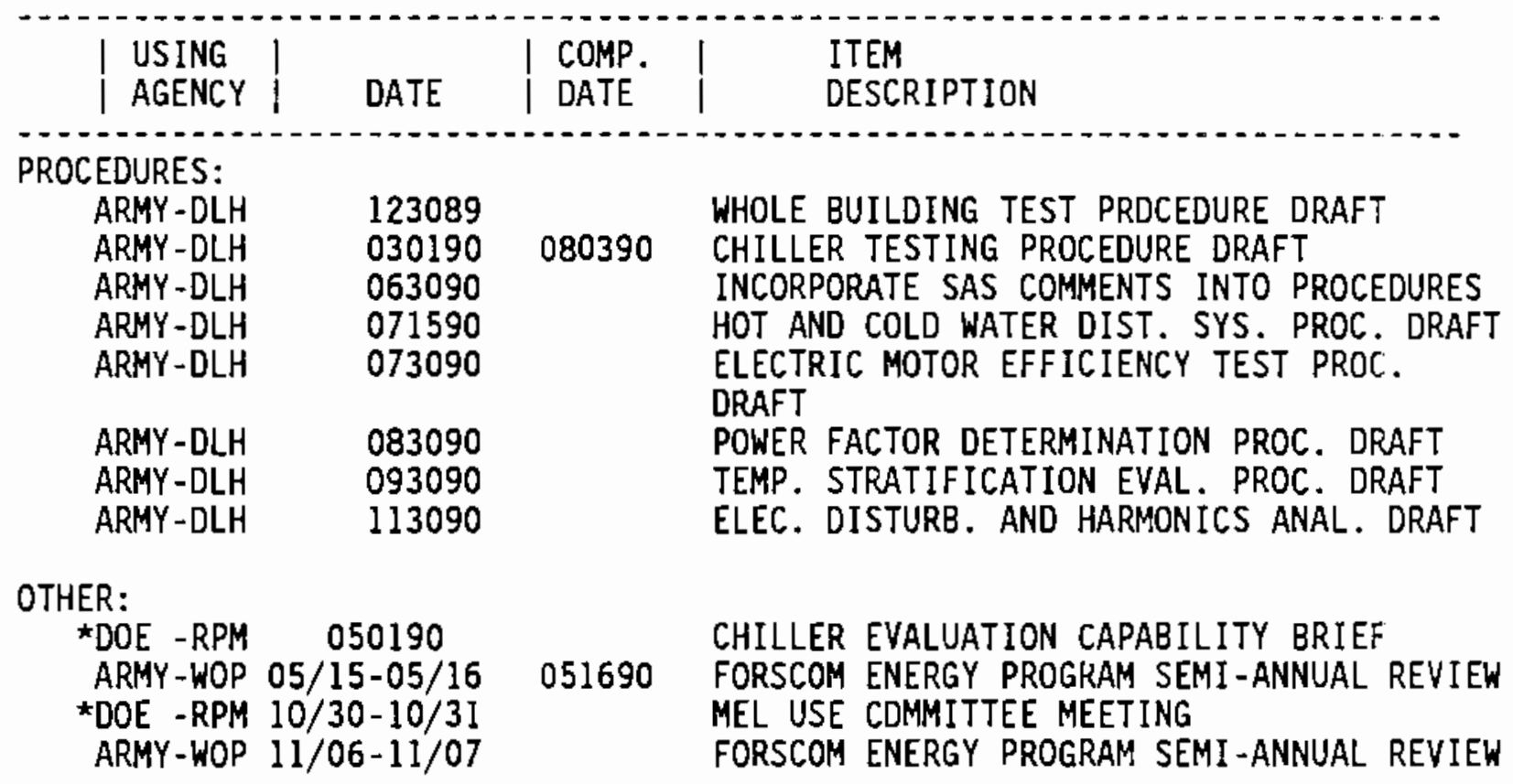

* MEL-related activities not funded by FORSCOM 


\section{Attachment 4}

NEESA MEL HISTORY AND STATUS 


\title{
MOBILE ENERGY LABORATORY \\ USE COMMITTEE MEETING \\ March 29-30 1990
}

\begin{abstract}
Background. Per a 1984 interagency agreement between DOE and DON, NEESA constructed and outfitted four mobile energy laboratories (MELs). Each MEL is:

Self-contained and transportable.

Capable of performing energy audits, surveys, and anaiyses suitable to develop energy budgets, energy conservation projects, and baselines for shared savings contracts.
\end{abstract}

The MELs were modeled after a NEESA Energy Van, consisting of a Travco RV that provided transportation and work space, and steam, electrical, and combustion monitoring equipment.

One MEL each was to be assigned to the Air Force, Army, Navy, and a civilian agency (to be determined by DOE). The MELs were constructed from refurbished Air Force buses and outfitted with equipment similar to equipment in use at NEESA. Because of the high cost of the equipment, minimum amounts were placed on each MEL, and it was left to individual agencies to "customize" the MELs to their needs. Construction was begun early in 1984 and the first article was completed in September 1984. The remaining MELs were completed by the end of CY 1985.

The first MEL was formally assigned to the Navy in 1984. However, because of strong interest at Fermilab, the Navy transferred the first MEL to Fermilab, and agreed to take the second MEL. Use of the MELs by Fermilab (DOE) and the Navy (NEESA) was extensive, but the Air Force and Army showed little interest in using the third and fourth MELs. NEESA had agreed to provide training in use of the $M E L$ to each agency, and did for Fermilab and Argonne personnel. Eventually, the Army MEL was placed at Fort Sheridan, and training was provided to individuals there. No training was provided to Air Force personnel.

Navy Use of MEL. NEESA is a facilities engineering support activity for the Navy. We provide direct assistance to Navy shore actlvities in energy and utlittes. Consequently, we have an extensive inventory of energy and utilities test and analysis equipment. Our standard way of doing business was the model for the MELs. When we received the Navy's MEL, we incorporated it into our inventory and our business. Our use of MEL has continued-not as a stand-alone MEL-but as part of our normal operation.

Current NEESA Role. In 1987, NEESA and.DOE entered another interagency agreement for NEESA to provide continued engineering support for the MELs, through FY90. Engineering support included field assistance, training, and equipment repair and calibratton. To the extent funds were available, NEESA was willing to procure additional equipment for the MELs. Currently, we have about \$57K of DOE funds remaining, and $\$ 23 K$ in existing equipment requests, leaving a balance of $\$ 34 K$ for field assistance and equipment.

As a MEL user, our use of MEL and the equipment continues as part of our normal operations. Since 1985, we have augmented our operations with additional equipment including leak detection equipment, infrared imaging equipment, HVAC equipment, data loggers, other flow meters, and power disturbance analysis equipment. Much of the equipment originally procured for the Navy's MEL has been excessed (e.g.-data loggers, disk data recorders), upgraded (e.g.-steam meter flow processors, Dranetz power analyzers), or worn out or destroyed during use. 
Future NEESA Role. Severe constraints on the numbers of personne! working in Program iX (Utilities and Energy) make NEESA's ability to provide continued engineering support to the MEL progran after FY90 doubttul.

Recent NEESA MEL Operations. The following are representative NEESA projects that utilize the MEL concept:

$\S \quad$ Performed HVAC upgrades/installed single building controilers/direct digital control systems at the following sites:

NADEP Alameda, Building 7 - Instailed DDC system as retrofit to existing controls in one building (Oct 1988). We are continuing to monitor SBC contol system to model energy use and to document energy savings.

PWC Norfolk - Completed 80 point supervisory DDC installation October 1989. Four digital controllers control 6 AHUs and lighting at Building A-81. Considerable energy savings will result from the new control system. PWC is assisting us in quantifying energy savings.

PMTC Mugu - Installed DDC system as retrofit to existing controls in one building (Oct 1989).

NAVSSES Philadelphia - Completed 130 point DDC installation 20 December 1989. We returned for final system testing in February 1990. Seven digital controllers control 7 AHUs, 32 hot water vaives, 13 fan coil units, a chiller, steam valve, unit heaters, and lighting at Building 29. Implemented control strategies, (hot water reset, night setback, timeclocking, optimum start/stop, modulating control of heating and cooing, and sensor based set points) will greatly reduce energy consumption of the building. We will quantify these energy savings and publish the results. We performed a reconnaissance to convert another NAVSSES building to DDC as part of the above return tsip in February 1990.

NADEP Alameda, Building 530 - DDC system instailation will be completed after AHU modifications. This work is expected to be completed in June 1990 with installation to follow.

NADEP North Island - We received funding to trouble shoot an existing, inoperable, Barber-Coleman control system. This system controls tire pneumatic controls for their materials lab building. We will investigate converting the building to DDC in 3rd quarter 1990.

\$ Shared energy savings work:

Updated NAVHOSP Long Beach energy baseline prior to contract award in October 1989 
$\S$ Metering:

NAS Oceana - Performed steam distribution system analysis in JulyAugust 1989. Finai report of the steam distribution system analysis recommends summer steam shutdown (\$136,000 annual savings), and decentralization of steam system (1 year payback).

NSY Long Beach - Installing steam metering system at NSY Long Beach to quantify steam to industrial areas, piers, and tenants. Steam metering systern will probably be complete summer 1990. This will end mult-year project to define industrial energy costs at NSY Long Beach.

MCAGCC Twentunine Palms - High temperature hot water data collected at 31 points to determine system capacity and future expansion capability. Data also collected on heat exchangers and primary loop in central plant to determine source of vibration problems in primary loop. This data was reduced and forwarded to the contractor Nov. 89.

NS Norfolk - Performed metering of steam distribution system to estimate loads, system efflciency, and losses in underground piping. Results showed excellent paybacks on summer steam shutdowns and replacement of underground piping with an aboveground system.

PWC San Diego, Sait Water Pumps - Tested systems at Pier 1 and Mole Pier, and identified electrical problems. NEESA plans to repair these systems by 3 rd quarter FY90. Identified electrical problems at Piers 2 , 6 , and 8 . Conducted harmonic test at Pier 12 and rejected drive/motor system. Pier 12 work scheduled for completion, Jan. 90. Reviewed $100 \%$ specification submittal for Point Loma pump system. Anticipate approval of design, Jan. 90.

$\S$ Cogeneration

MCB Camp Pendleton - Completed electrical and ffuid metering at severa! orus and mess halls at MCB to determine feasibility of smail cogeneration systems. Contract awarded to install wo systems. Installation currently underway.

$\S \quad$ Thermal Energy Storage

NAVHOSP San Diego - Performed metering to model energy usage profile to size thermal energy storage faciitity.

Mr, B Camo Pendleton Pertormed metering to model energy usage protile to determıne feasibility and sizing of thermal energy storage system. 
MCB Camp Pendleton - Conducted reconnaissance visit of site and requested water consumption data. Prefiminary assessment shows potential for $60 \mathrm{~kW}$ system. Will require metering to determine water flow profiles.

PMTC Point Mugu - Analyzed electrical distribution system to determine design for remote metering system. One remote metering system has been installed. We plan to install 3 additional remote metering systems as part of a pilot project before installing a more extensive system for sillina.

Army, Fort Bliss - NEESA developed an energy consumption baseline model to provide data for the "before" condition prior to award of a shared savings contract. Later we installed a meter to provide "after" data, but the shared savings contract has not yet been awarded. Consequently we decided to monitor energy data for one year, and compare it to the energy consumption model. Additionally, we will provide an electrical consumption profile, including demand and timeof-use data. We installed a remote recorder during 2nd quarter of FY90 so that we can monitor data from NEESA.

Naval Hospital, Great Lakes - Analyzed steam and electrical distribution system to design permanent metering system. Report forwarded Jan 90 detailing metering system design. Installation of steam and electrical remote metering systems anticipated end of 4th quarter FY90.

$\S \quad$ Activity self help: We often loan equipment to activities with short term requirements.

NAS Patuxet River--8 electric meters

NAS Pt. Mugu--8 electric meters

NSY Mare Island- -1 steam meter

NEESA Mission Requirements. NEESA is a unique organization in the Navy. Much of our success is attributable to our ability to rapidfy respond to requests from field activities with engineering expertise and equipment. Any arrangement that would compromise our response capability would be unacceptable.

Our use of equipment is heavy and often lengthy. For example, we have had metering equipment installed at sites for up to 18 months to establish energy models. We require sufficient equipment to be able to support lengthy monitoring times, as well as compensate for equipment failure, and still respond to other activities' requests. To meet our mission requirements, maximum equipment availability is essential. 
Attachment 5

URBAN MASS TRANSPORTATION ADMINISTRATION LETTER 
U.S. Descrtit.ent

of ircisporicticn

Urban Mass

Transportatian

Administration

Mr. William Riches

Fermi National Accelerator Laboratory

PO Box 500

Batavia, IL 60510
Central Area Olice

Region 5
¿ E East Mcnrce Sireet Eulte :415

Eiricaco. illuners sogos

HAR : 2 ISSO

Re: Coordination of Transporiation and Energy Conservation Programs in L.S. DOT Rezion 5

Dear Mr. Riches:

To follow up our conversations on how we can better coordinate our activities on the regional level I am providing a bries outline of our clients and programs.

The Urban Mass Transportacion Administration (UMTA) is part of the U.S. Department of Transportation and funds the following state and local agencies:

- State Departments of Transportation (planning and capical granis)

- Metropolitan Planning Organizations (MPO's are required for each urbanized area; planning grants only)

- Transit agencies (planning and capital grants)

UMTA allocates approximately $\$$ is million annually to support planning activities of the MPO and Sizte transportation agencies. These planning activities focus on long range transportation plans, short range transportation system management plans, and more specialized studies including energy conservation. UMTA also spends approximately 52.3 billion for the purchase of buses, rail cars and ocher transit vehicles, and the construction of garages, rail systems, and passenger lacilities. UMTA funds may be used by iransit agencies for cnergy conservation projects.

As part of our effort to explain and coordinati UMTA's program with grantees we hold regional transit meerings and teetnical assistance meetrags with the six state transit agencies in Region 5. We discuss UMTA's alternative fue!s program at these mestings and ate considering a diseussion of energy conservation and recyeling erforts. If we do include discussions of energy conservation, it would be important to coordinate with the Department of Ene:zy. It may also be appropriate to demonstrate the Mobile Energy Laboratory (MEL) and discuss how our grantees can use it to evaluate the savings potential of energy conservation projests for their administrative and vehicle operating izciliries. UMTA grances include large cransit agercies such as the Caicago Transit futhority as well as state and city administrative oifices.

Would you lec me know how the MEL might be used by our grancess, and how we might berter coordinate our agencics activities at the regional level. Wy phone number is FTS $353-2983$.

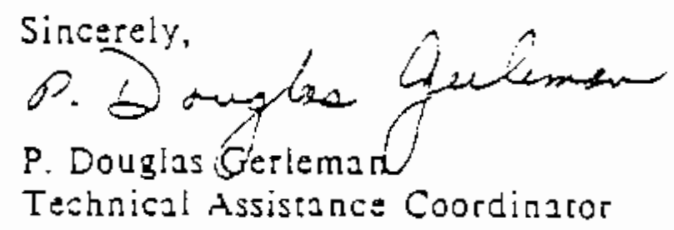



ATTACHMENT 2

PACIFIC NORTHWEST LABORATORY APPRAISAL REPORT FORM 
INSTAILATION:

INSTALIATION CONDACT:

ACTIVITY:

PNL TECHNICAL LEAD(S) :

Camienss

RATING

Technical competence

\& Understanding of

Issues

Adequacy of

Planning

quality of

Work

Timliness of

Data \& Reporting

Responsiveness to

Installation Needs

Quality of RNL

Staff

(Note: Use Back of Page for Additional Conments.)

Ratings Key:

$0=$ outstanding

$E=$ Excellent

$\mathrm{G}=\mathrm{Good}$

$M=$ Marginal

$U=$ Unsatisfactory
Return Form To:

Mr. James Vasiloff

Commander FORSCOM

FCEN-RDE/ETVirorment

Fort McPherson, GA 30330-6000 
$$
\text { . }
$$ 
ATTACHMENT 3

STATUS OF FORSCOM MAPS 
STATUS OF FORSCOM MAPS

$10 / 01 / 90$

MAP \#
FORT CARSON
CARSON-001
CARSON-002
CARSON-003
FORT LEWIS
LEWIS-001
LEWIS-002
LEWIS-003
LEWIS-004
LEWIS-005
LEWIS-006-R1
LEWIS-007-R1
LEWIS-008
LEWIS-009

TEST DESCRIPTION

[Initia] Site Visit 01/89]

Building 8030 Lighting and End Use Metering Combustion Efficiency/Waste 0il Burn 8uilding 8000 Compressor Evaluation

[Initiai Site Visit 05/89]

Power Factor at Yakjma Firing Range Electrical Distribution System Profile Sewage Treatment Plant Profile Lighting Levels in Building Commissary Electric Usage Profile Stean \& HTHW Boiler Testing Barracks Heat Demand Helicopter Hanger Retrofit Evaluation Helicopter Simulation Building Tripout
STATUS

Taking Data Until 06/91

Equipment Remains $09 / 90$ Taking Data Unti\} 10/90

Unsigned by DEH

Equipment Removed 12/89

Equipment Removed 12/89 Unsigned by $\mathrm{DEH}$

Equipment Removed 12/89 Testing to Start $01 / 91$ Testing to Start $01 / 91$ Unsigned by $\mathrm{DEH}$

To be Revised

FORT SAM HOUSTON [Initial Site Visit 08/89]

FSAMH-001

FSAMH -002

FSAMH -003

FSAMH-004

FORT IRWIN

IRWIN-001

IRWIN-002

IRWIN-003
Air Conditionor Constroller Evaluation Chiller Performance Evajuation Hot Water Controller Evaluation Laundry 8oiler Combustion Efficiency
Equipment Removed 08/89 Testing to Start $10 / 90$ Testing to Start $10 / 90$ Testing to Start $10 / 90$

HUNTER ARMY AIR FIELD [Initial Site Visit 10/89]

HUNTR-001

HUNTR-002

FORT STEWART

STWRT -001-RI STWRT -002-R1

FORT MCPHERSON

FTMAC-001

FTMAC -002

FTMAC-003
[Initia] Site Visit 09/89]

Electrical Distribution System Profile Office Building Electric Use Profile office Building Lighting Levels

Testing Started Testing Started $03 / 90$ Testing Completed $12 / 89$

Electrical Distribution System Profile Chiller Performance Evaluation

Taking Data Until 09/91 Testing Completed 09/90

[Initia] Site Visit 10/89]

Electrical Distribution System Profile Main Power Plant Electric Use Profile

Testing Completed $09 / 90$ Taking Data Until 05/91

$$
\text { [Initial Site Visit 11/89] }
$$

Boiler Combustion/Delivery Efficiency Building 200 Electric Profile Combustion Efficiency Small Boilers
Equipment Removed 08/90 Testing Started $02 / 90$ Equipment Removed 08/90 
FORT GILLEM [Initial Site Visit 11/89]

FTGIL-001 Warehouse Temperature Stratification

FTGIL-002

Boiler Shutdown Evaluation

Testing to Start $01 / 91$

FORT ORD

[Initiai Site Visit 04/90]

Testing to Start $01 / 91$

FTORD-001

FTORD -002

Peak Demand at PX and Meter Calibration Well Water Pumps Electric Demand

Site Visit Report $04 / 90$

FTORD -003

FTORD -004

FTORD - 005

Electrical Distribution System Profile Hospital End Use Characterization

Hospital Boiler Delivery Efficiency

FORT RILEY

[Initia] Site Visit 07/90]

Site Visit Report 07/90

RILEY-001

RILEY-002

Electricl Distribution System Profile Chiller Delivery Efficiency

Signed by $\mathrm{DEH}$

$09 / 90$

RILEY-003

Chiller Cooling Load Determination

signed by DEH

$09 / 90$

Signed by DEH

$09 / 90$ 
ATTACHMENT 4

INITIAL SITE VISIT REPORT FORM 
INITIAL SITE VISIT REPORT FOR

[SITE RAME]

PREPARED BY PACIFIC NORTHWEST LABORATORY

FEDERAL ENERGY MANAGEMENT PROGRAM

\author{
PREPARED FOR THE UNITED STATES ARMY \\ HEADQUARTERS FORCES COMMAND
}

PREPARED BY:

DATE:

$\mathrm{Ph} \#$

APPROVED BY:

DATE:

Ph\#

Prepared for the U.S. Army Forces Command under a Related Services Agreement with the U.S. Department of Energy Federal Energy Management Program Contract DE-AC06-76RLO 1830 


\subsection{INTRODUCTION}

This report documents the initial site visit by Pacific Northwest Laboratory (PNL) staff to ascertain candidate testing activities for the Mobile Energy Laboratory (MEL). The MEL is operated by PNL for the U.S. Department of Energy (DOE) Federa] Energy Management Program (FEMP). The U.S. Army Forces Command (FORSCOM) has contracted with DOE/FEMP to apply the MEL for energy-efficiency testing activities at selected FORSCOM installations.

\subsection{INSTALLATION VISITED}

\subsection{DATES VISITED}

\subsection{PNL STAFF}

Listing of PNL staff, position and phone number.

\subsection{INSTALLATION STAFF CONTACTED}

Listing of installation staff, position and phone number.

\subsection{TESTS REQUESTED BY INSTALLATIDN}

Listing of requested tests. Copy of test request letter/form attached to the report.

\subsection{RECOMHENDED TESTS/TEST PROCEDURE}

Listing of the tests recommended by PNL and the test procedure to be used for each test. This list is repeated in Appendix A with space provided for comment and approval signoff prior to completing a MEL Assignment PTan for the test.

\subsection{DISCUSSION}

A general discussion will be followed by specific discussion on each test recommended by PNL in Section 7.0.

\subsection{DOCUMENTATION AND INFORMATION ACQUIRED}

Listing/description of documents acquired from the installation during the site visit.

\section{ATTACHMENTS}

- Installation Request for MEL Testing

- PNL Trip Report 
APPENDIX A

TEST APPROVAL
Test

Test \#1 [Description]

Test \#2 [Description]

Test \#3 [Description]

* Recommended Changes/Comments
Approval

[ ] Approved As Described

[ ] Approved With Changes*

[ ] Not Approved*

[ ] Approved As Described

[ ] Approved With Changes* Not Approved*

[ ] Approved As Described Approved With Changes* Not Approved*

APPROVED BY:

DATE: 


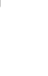


ATTACHMENT 5

MEL WRITEUP FOR SAS CORPS OF ENGINEERS 


\section{ENERGY EFFICIENCY TESTING USING}

THE MOBILE ENERGY LABORATORY

Energy use data collection, automated recording, reduction and analysis equipment is available to test the efficiency of energy conversion and distribution systems, as well as specific energy end-use applications at federal installations. A secondary standards Mobile Energy Laboratory (MEL) contains the specialized test equipment and procedures, and provides a secure work place when needed at a facility. The MELs are operated by Pacific Northwest Laboratory (PNL) for the Department of Energy's Federa] Energy Management Program in association with other sponsoring federal agencies.

The test equipment presently includes electrical, steam, hot and chilled water metering systems, light meters, combustion efficiency analyzers, temperature and humidity recorders, and ventilation and air flow measurement devices. In addition, portable computers are used to acquire, process, analyze, and display data. Trained PNL engineers and specialists work with installation personnel to identify and conduct tests as appropriate.

Once a test is completed, PNL prepares a test report that includes recommend actions for increasing energy efficiency, and a life-cycle cost analysis if appropriate. Test reports and summarized test data are provided to the Corps of Engineers, Savannah District (SAS) for review and transmittal to the installation. The test results can provide valuable information to the installation in the development of an overall strategy for reducing energy usage.

Recent testing activities at Forces Command installations include:

- electrical distribution system evaluation (Ft. Lewis, Ft. Irwin Ft. Stewart, Hunter Army Air Fjeld)

- building-Tevel total electrical and end use evaluation (Ft. Carson,

Ft. Lewis, Ft. McPherson, Ft. Irwin)

- Targe and small boiler combustion and delivery efficiency (Ft. Carson,

Ft. McPherson)

- majn power plant electric profile (Ft. Stewart)

- lighting levels survey in office buildings (Ft. Irwin)

- temperature controller evaluation (Ft. Sam Houston)

- temperature stratification (Ft. Gillem)

- electric power quality evaluation (Ft. Lewis).

Future testing activities and capabilities will include:

- chiller delivery efficiency

- remote metering and display of energy usage

- boiler dajiy shutdown evaluation

- heating, ventilating, and air conditioning (HVAC) system evaluation

- electric motor efficiency evaluation

- renewabie energy and cogeneration assessment.

IPacific Northwest Laboratory is operated by Battelle Memoria? Institute for the U.S. Department of Energy under Contract DE-ACO6-76RLO 1830. 



\section{DISTRIBUTION}

No. of

Copies

OFFSITE

2 DOE/Office of Scientific and Technical Information

10 K. D. Devine

Federal Energy Management Program

U.S. Department of Energy 1000 Independence Avenue SW CE-10.1 6A-034/FORS Washington, DC 20585

2 T. Thomas

Forces Command

FCEN-RDE/Environment

Fort McPherson, GA 30330-6000

S. Hathaway

HQAFESC/DEMGR

U.S. Air Force Engineering and Services Center

Tyndal1 AFB, FL 32403-6001

J. Heller

Naval Energy and Environmental

Support Activity

111E2

Port Hueneme, CA 93043-5014

V. Kuchler

Fermi National Accelerator

Laboratory

P.0. Box 500

Batavia, IL 60510

B. Plunkett

Corps of Engineers-Savannah

100 West Oglethorpe Avenue

Savannah, GA 31401-3640
No. of

Copies

Director

Engineering Housing and

Support Center

Fort Belvoir, VA 22060

Director

U.S. Army Construction

Engineering Research

Laboratory

P.0. Box 4005

Champaign, IL 61820-1305

\section{ONSITE}

DOE Richland Operations Office

R. B. Goranson

25 Pacific Northwest Laboratory

R. Bartlett

J. W. Currie (5)

B. A. Garrett (2)

B. L. Mohler

G. B. Parker (5)

T. J. Secrest (2)

R. F. Szydlowski

Project File (2)

Publishing Coordination

Technical Report Files (5) 
